\title{
Additions and Range Extensions to the Vascular Plant Flora of the Continental Northwest Territories and Nunavut, Canada III
}

\author{
William J. CODY ${ }^{1}$ and KENNETh L. READING ${ }^{2}$ \\ ${ }^{1}$ Biological Resources Program, Biodiversity, National Program on Environmental Health, Agriculture and Agri-Food Canada, \\ Wm. Saunders Building (49), Central Experimental Farm, Ottawa, Ontario K1A 0C6, Canada \\ ${ }^{2} 11$ Colborne Street, Thornhill, Ontario L3T 1Z4, Canada
}

Cody, William J,. and Kenneth L. Reading. 2005. Additions and range extensions to the vascular plant flora of the continental Northwest Territories and Nunavut, Canada III. Canadian Field-Naturalist 119(2): 276-290.

Fifteen native taxa are reported as new to either District of Keewatin (now Nunavut in part) or District of Mackenzie (Nunavut contains the northeastern portion): Aster puniceus, Astragalus eucosmus, Astragalus eucosmus f. albinus, Carex media, Epilobium latifolium f. albiflorum, Eriophorum viridi-carinatum, Erysiumum pallasii, Moneses uniflora, Najas flexilis, Potamogeton obtusifolius, Salix arctica $\times$ glauca, Salix glauca ssp. callicarpae, Salix myrtillifolia, Salix rotundifolia, Shepherdia canadensis, taxa are new to Northwest Territories overall. Significant range extensions for 157 native taxa are included.

Key Words: Vascular plants, Mackenzie, Keewatin, Nunavut, flora, new records, range extensions, phytogeography.

Since the publication of Additions and Range Extensions to the Vascular Plant Flora of the Continental Northwest Territories and Nunavut, Canada II (Cody et al. 2003) a large number of specimens collected by Kenneth L. Reading in the Continental Northwest Territories between the years of 1978 and 1995 were discovered and forwarded to the senior author for examination. Many of these proved to be significant records and are reported here along with some additional specimens collected by D. Bush, D. Campbell, B. Cornish, V. J. Kajima, L. Kershaw, J. B. Korol, J. Lancaster, J. V. Matthews, J. W. Thieret, R. J. Reich, and J. Thompson.

All of these specimens are preserved in the Agriculture and Agri-Food Canada Herbarium (DAO). As in Cody et al (2003) the authors have continued to use the historic names "District of Keewatin" and "District of Mackenzie" to follow the format of Porsild and Cody (1980) Vascular Plants of Continental Northwest Territories and subsequent publications. However, continental "Keewatin" and the former northeastern portion of "District of Mackenzie" are now part of the recently defined Continental Nunavut Territory.

As in paper II a synopsis of the taxa addressed in the body of this paper follows with species listed in alphabetical order within categories. The taxa are then discussed in an annotated list by family in the same order as presented in the Flora of the Continental Northwest Territories (Cody and Porsild 1980) together with citation of specimens and other pertinent information.

\author{
New Taxa to the Continental Northwest \\ Territories Status \\ New Taxa to the Continental Northwest Territories \\ (Keewatin): (10) \\ Astragalus eucosmus \\ Astragalus eucosmus f. albinus \\ Carex media \\ Epilobium latifolium f. albiflorum
}

\author{
Eriophorum viridi-carinatum \\ Erysimum pallasii \\ Moneses uniflora \\ Salix glauca ssp. callicarpaea \\ Salix myrtillifolia \\ Shepherdia canadensis
}

New Taxa to the Continental Northwest Territories
(Mackenzie): (5)

Aster puniceus

Potamogeton obtusifolius

Najas flexilis

Salix arctica $X$ glauca

Salix rotundifolia

\section{Range Extensions of Native Taxa in the Continental}

Northwest Territories (Keewatin): (48)

Anemone parviflora

Anemone richardsonii

Antennaria isolepis

Caltha natans

Campanula uniflora

Cardamine bellidifolia

Cardamine pratensis

Carex canescens

Carex rariflora

Carex rotundata

Carex scirpoidea

Cystopteris fragilis

Draba fladnizensis

Draba nivalis

Draba wahlenbergii

Dryopteris fragrans

Epilobium davuricum

Equisetum palustre

Festuca brachyphylla

Galium trifidum

Juncus arcticus

Juncus castaneus ssp. castaneus

Ledum groenlandicum

Minuartia biflora

Minuartia rossii 
Minuartia rubella

Polygonum viviparum

Potentilla nivea ssp. nivea

Potentilla palustris

Pyrola secunda

Ranunculus sabinei

Ranunculus $\times$ spitzbergensis

Rubus arcticus $\mathrm{ssp}$. acaulis

Rubus idaeus

Sagina caespitosa

Salix arctophila

Salix fuscescens

Salix planifolia

Salix reticulata

Salix richardsonii

Saxifraga nelsoniana ssp. porsildiana

Saxifraga rivularis

Scirpus caespitosus ssp. austriacus

Silene walensis

Stellaria calycantha

Stellaria longipes

Tofieldea coccinea

Tofieldia pusilla

Range Extensions of Native Taxa in the Continental Northwest Territories (Mackenzie): (109)

Alisma triviale

Anemone parviflora

Arctostaphylos alpina

Arnica angustifolia ssp. attenuata

Arnica chamissonis

Artemisia furcata

Artemisia tilesii

Aster pygmaeus

Aster sibiricus

Astragalus australis

Braya glabella

Braya humilis

Calamagrostis lapponica

Calamagrostis purpurascens

Calamagrostis stricta ssp. stricta

Callitriche hermaphroditica

Caltha palustris var. arctica

Cardamine bellidifolia

Carex bebbii

Carex nardina

Carex scirpoidea

Carex subspathacea

Carex supina ssp. spaniocarpa

Carex vaginata

Cerastium alpinum

Cerastium beeringianum

Chenopodium dessicatum

Chrysosplenium tetrandrum

Crepis nana

Cryptogramma crispa var. acrostichoides

Cystopteris fragilis

Cystopteris montana

Danthonia spicata

Descurainia sophioides

Draba juvenalis

Draba wahlenbergii

Dryopteris fragrans

Elymus canadensis

Elymus macrourus
Elymus trachycaulus ssp. violaceus

Epilobium palustre

Equisetum palustre

Erigeron uniflorus ssp. eriocephalus

Eriophorum angustifolium

Eriophorum callitrix

Eriophorum triste

Eriophorum vaginatum

Erysimum pallasii

Eutrema edwardsii

Festuca richardsonii

Gentiana affinis

Hedysarum alpinum

Hedysarum boreale ssp. mackenzii

Hierochloe hirta ssp. arctica

Juncus arcticus

Juncus castaneus ssp. castaneus

Juncus stygius ssp. americanus

Juncus triglumis ssp. albescens

Juniperus communis

Lagotis glauca

Limosella aquatica

Linnaea borealis var. americana

Lupinus arcticus

Luzula wahlenbergii

Lycopodium selago

Lycopus uniflorus

Matricaria ambigua

Minuartia yukonensis

Muhlenbergia glomerata

Myriophyllum alterniflorum

Nymphaea tetragona ssp. leibergii

Oxytropis arctobia

Oxytropis deflexa ssp. foliosa

Oxytropis maydelliana

Papaver radicatum

Parrya arctica

Pedicularis capitata

Pedicularis langsdorfii ssp. arctica

Pedicularis lapponica

Pedicularis macrodonta

Phragmites australis

Poa alpina

Poa glauca

Poa pratensis ssp. alpigena

Potamogeton filiformis

Potamogeton foliosus

Potentilla biflora

Ranunculus aquatilis var. eradicatus

Rosa blanda

Rhynchospora alba

Salix alaxensis

Salix arctica

Salix glauca var. acutifolia

Salix planifolia

Salix reticulata

Salix richardsonii

Salix sphenophylla

Saxifraga nivalis

Scirpus rollandii

Senecio congestus

Silene walensis

Solidago graminifolia var. major

Sparganium hyperboreum

Spartina gracilis 
Stellaria longipes

Triglochin maritimum

Trisetum spicatum

Vaccinium vitis-idaea var. minus

Woodsia ilvensis

\section{Annotated List}

\section{LYCOPODIACEAE}

Lycopodium selago L., Mountain Club-moss MACKENZIE: Hope Bay Area, northeast of Bathurst Inlet, Windy Lake, $68^{\circ} 03^{\prime} 15^{\prime \prime} \mathrm{N} 106^{\circ} 37^{\prime} 00^{\prime \prime} \mathrm{W}, K$. Reading 152, 14 July 1987 (DAO).

The specimen cited above is an extension of the known range in the Territory of about 175 kilometers north of a site adjacent to the Arctic Circle (Porsild and Cody 1980).

\section{EQUisETACEAE}

Equisetum palustre L., Marsh Horsetail - MACKENZIE: muddy tundra pond margin, Coppermine River Area, 67³1'15"N 11601'00"W, K. Reading 8, 31 Aug. 2002 (DAO); rocky fen pools, Coppermine River Area, 67³3'30"N 116 $14^{\prime} 54^{\prime \prime W, ~ K . ~ R e a d i n g ~ 47, ~} 21$ Aug. 2002 (DAO); muddy flooded rock polygon, Coppermine River Area, $67^{\circ} 34^{\prime} 00^{\prime \prime} \mathrm{N} 116^{\circ} 17^{\prime} 00^{\prime \prime} \mathrm{W}$, K. Reading 9, 1 Sept. 2002 (DAO); Hope Bay Area, northeast of Bathurst Inlet, Windy Lake, $68^{\circ} 03^{\prime} 15^{\prime \prime N} 106^{\circ} 37^{\prime} 00^{\prime \prime W}$. K. Reading 204, 16 July 1987 (DAO); KeEwatin: SY Area, $62^{\circ} 12^{\prime} 20^{\prime \prime N} 97^{\circ} 52^{\prime} 00^{\prime \prime W}$, K. Reading 121, 17 Aug. 1984 (DAO).

The first four specimens cited above extend the known range of this species about 500 kilometers northeast of the east end of Great Bear Lake (Porsild and Cody 1980). The fifth specimen is about 170 kilometers south of the only previously known localities in central KEEWATIN (Cody et al. 2003).

\section{PTERIDACEAE}

Cryptogramma crispa (L.) R.Br. var. achrostichoides (R.Br.) C.B. Clarke, Mountain-parsley - MACKENZIE: common on outcrop, $63^{\circ} 00^{\prime} 00^{\prime \prime} \mathrm{N} 109^{\circ} 55^{\prime} 00^{\prime \prime} \mathrm{W}, K$. Reading 426, 8 Aug. 1995 (DAO).

The specimen cited above is an extension of the known range in the Territory of about 85 kilometers northeast of the east end of Great Slave Lake (Porsild and Cody 1980).

\section{ASPIDIACEAE}

Cystopteris fragilis (L.) Bernh., Fragile Fern MACKENZIE: $63^{\circ} 00^{\prime} 00^{\prime \prime N} 109^{\circ} 55^{\prime} 00^{\prime} \mathrm{W}$, K. Reading 423, 11 Aug. 1995 (DAO); KeEwatin: Griffin Lake, $61^{\circ} 17^{\prime} 20^{\prime \prime N} 98^{\circ} 42^{\prime} 00^{\prime \prime} \mathrm{W}, K$. Reading 98, 19 Aug. 1990 (DAO).

The first specimen cited above is an extension of the known range in the Territory of about 70 kilometers northeast of the east end of Great Slave Lake and the second specimen is the southernmost yet known in the District of Keewatin (Porsild and Cody 1980).

Cystopteris montana (Lam.) Bernh., Mountain Bladder Fern - MACKENZIE: uncommon under tamaracks, $63^{\circ} 00^{\prime} 00^{\prime \prime N} 109^{\circ} 52^{\prime} 00^{\prime \prime W}$, K. Reading 429, 9 Aug. 1995 (DAO).

This is a rare species in the Continental Northwest Territories which Porsild and Cody (1980) knew from only three localities west of the west end of Great Slave Lake. The specimen cited above is an extension of the range to the east of Great Slave Lake of about 390 kilometers.

Dryopteris fragrans (L.) Schott, Fragrant Cliff Fern MACKENZIE: Hope Bay Area, northeast of Bathurst Inlet, Roberts Lake, 68 $18^{\prime} 30^{\prime \prime} \mathrm{N} 106^{\circ} 33^{\prime} 00^{\prime \prime} \mathrm{W}$, K. Reading 231, 11 Aug. 1987 (DAO); KeEWATIN: south south-

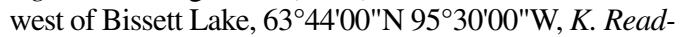
ing 336, 28 Aug. 1982 (DAO).

This is a widespread species in Canada. The first specimen cited above is an extension of the known range of about 180 kilometers north northwest from the Arctic Circle and the second specimen is from a site between two sites south of the Arctic Circle (Porsild and Cody 1980).

Woodsia ilvensis (L.) R.Br., Rusty Woodsia - MACKENZIE: $63^{\circ} 00^{\prime} 00 " \mathrm{~N} 109^{\circ} 55^{\prime} 00^{\prime \prime} \mathrm{W}, \mathrm{K}$. Reading 425, 8 Aug. 1995 (DAO); outcrop beside bog, 62 $59^{\circ} 00^{\prime \prime N}$ 109 51'00"W, K. Reading 428, 9 Aug. 1995 (DAO); Hope Bay area, northeast of Bathurst Inlet, Roberts Lake, $68^{\circ} 10^{\prime} 30^{\prime \prime} \mathrm{N} 116^{\circ} 33^{\prime} 00^{\prime \prime} \mathrm{W}$, K. Reading 213, 11 Aug. 1987 (DAO).

The first two specimens cited above are an extension of the known range in the Territory (Porsild and Cody 1980) of about 170 kilometers northeast of a site near the east end of Great Slave Lake. The second specimen is a northward extension of about 75 kilometers from a site reported by Cody et al. (1984).

\section{CUPRESSACEAE}

Juniperus communis L. s.1., Ground Juniper - MACKENZIE: dolomite scarp, Coppermine River Area, 67 $09^{\prime} 00^{\prime \prime} \mathrm{N}$ $115^{\circ} 45^{\prime} 00^{\prime \prime} \mathrm{W}$, K. Reading 83, 28 Aug. 2002 (DAO).

The specimen cited above is an extension of the known range in the Territory of about 170 kilometers northeast of a site at the east end of Great Bear Lake (Porsild and Cody 1980).

\section{SPARGANIACEAE}

Sparganium hyperboreum Laest. - MACKENZIE: big pool in creek, Coppermine River Area, 67 $31^{\circ} 10^{\prime \prime} \mathrm{N}$ $116^{\circ} 10^{\prime} 05^{\prime \prime W}$, K. Reading 52, 22 Aug. 2002 (DAO).

The specimen cited above is from a site midway between a site north of the east end of Great Bear Lake and the south end of Bathurst Inlet (Porsild and Cody 1980). This species was only found once in this area.

\section{Potamogetonaceae}

Potamogeton filiformis Pers., Fine-leaved Pondweed - MACKENZIE: sandy Lake, Coppermine River Area,

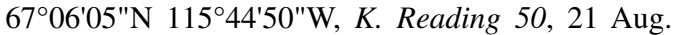
2002 (DAO).

The specimen cited above is from a site midway between a site north of the east end of Great Bear Lake and Bathurst Inlet (Porsild and Cody 1980).

Potamogeton foliosus Raf. (P. foliosus Raf. var. macellus Fern.), Closed-leaved Pondweed - MACKENZIE: $61.7382^{\circ} \mathrm{N} 121.1534^{\circ} \mathrm{W}$, L. Kershaw 18, 2003 (DAO).

This species was considered rare in the Northwest Territories by McJannet et al. (1995), who knew it only from the vicinities of Yellowknife, Nahanni National Park and the Great Bear River areas. The specimen cited above is from a site in the Keller Lake area east of the Mackenzie River. 
Potamogeton obtusifolius M.\&K., Blunt-leaved Pondweed - MACKENZIE: Mackenzie River-Yellowknife Highway, small lake at Mile 12.7 S, Thieret \& Reich 8358, 28 July 1961 (DAO); same area, small lake, Mile 38.3 S, Thieret \& Reich 4947, 23 July 1961 (DAO); $62.158^{\circ} \mathrm{N} 122.4891^{\circ} \mathrm{W}$, L. Kershaw 19, 2003 (DAO).

Porsild and Cody (1980) suggested that this species was to be expected in the southern parts of the Precambrian Shield area. Haynes (1974) reported it from the vicinity of Yellowknife. Haynes had already revised the first three specimens in 1971, but this revision was overlooked by Porsild and Cody. In 1995 he confirmed his identification. The fourth specimen cited above from a site near the Mackenzie River is an extension of the known range in the Territory of about 400 kilometers to the west.

\section{NAJADACEAE}

Najas flexilis (Willd.) Rostk. \& Schmidt, Wavy Water Nymph - MACKENZIE: beside beaver lodge near northwest corner of unnamed lake, $62.9854^{\circ} \mathrm{N} 123.1753^{\circ} \mathrm{W}$, L. Kershaw 14, 2003 (DAO).

The specimen cited above is new to the flora of the Continental Northwest Territories (Porsild and Cody 1980).

\section{SCHEUCHZERIACEAE}

Triglochin maritimum L., Seaside Arrow-grass - MACKENZIE: wet fen, Coppermine River Area, 67 $34^{\prime} 10^{\prime \prime} \mathrm{N}$ $116^{\circ} 18^{\prime} 50 " \mathrm{~W}$, K. Reading 153, 1 Sept. 2002 (DAO).

The specimen cited above is from a location midway between a site at the northeast end of Great Bear Lake and a site near the south end of Bathurst Inlet (Porsild and Cody 1980).

\section{Alismataceae}

Alisma triviale Pursh (A. plantago-aquatica L. var. americanum J. A. Schultes) - MACKENZIE: Willowlake River, $62.7024^{\circ} \mathrm{N} 123.1043^{\circ} \mathrm{W}$, sand and gravel bar on the north side of the river, D. Soppet 2, 2003 (DAO).

This species was considered rare in the Territory on the basis of a single collection from the shoreline of Hanging Ice River, north of Fort Smith (McJannet et al. 1995). The specimen cited above is an extension of the known range in the Territory of about 500 kilometers to the northwest.

\section{POACEAE}

Calamagrostis lapponica (Wahlenb.) Hartm. - MACKENZIE: Camp Peninsula on September (Mouse) Lake,

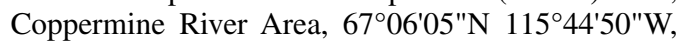
K. Reading 115, 24 Aug. 2002 (DAO).

The specimen cited above is from a site midway between the east end of Great Bear Lake and the south end of Bathurst Inlet (Porsild and Cody 1980).

Calamagrostis purpurascens $\mathrm{R}$.Br. - MACKENZIE: Hope Bay Area, northeast of Bathurst Inlet, Windy Lake, $68^{\circ} 03^{\prime} 15^{\prime \prime N} 106^{\circ} 37^{\prime} 00^{\prime \prime W}$, K. Reading 318, 29 June 1987 (DAO).

The specimen cited above is from a site about 170 kilometers north of the south end of Bathurst Inlet and is the most northwestern yet known from the District of Mackenzie (Porsild and Cody 1980).

Calamagrostis stricta (Timm) Koeler ssp. stricta $(C$. neglecta (Ehrh.) Gaertn., Mey. \& Scherb.) - MACKENZIE:
"Lunch outcrop", Coppermine River Area, 67³2'15"N $116^{\circ} 02^{\prime} 30^{\prime W}$, K. Reading 110, 26 Aug. 2002 (DAO); Hope Bay Area, northeast of Bathurst Inlet, Windy Lake, 6303'15"N 106³7'00"W, K. Reading 304, 15 July 1978 (DAO).

The first specimen cited above is from a site about 250 kilometers northeast of the east end of Great Bear Lake (Porsild and Cody 1980). To the north on Victoria Island it is known about 250 kilometers away, and to the east about 630 kilometers. The second specimen is from a site about 290 kilometers northeast of the first specimen location.

Danthonia spicata (L.) Beauv., Poverty Oatgrass MACKENZIE: along break between the sandbar and the Black Spruce forest on the edge of the river, north side sandbar of A River between Two Mountains, $62.942^{\circ} \mathrm{N}$ $123.0399^{\circ} \mathrm{W}$, D. Soppet 6, 2003 (DAO).

Porsild and Cody (1980) suggested that this species should be looked for along the southern rim of the Precambrian Shield east of the Slave River. Specimens which were all collected in Nahanni National Park and identified as $D$. intermedia have since been revised to D. spicata. The specimen cited above is from a site northeast of the park.

Elymus canadensis L., Canadian Wild Rye - MACKENZIE: upper shore of Mackenzie River about 100 m north of ferry landing, $62.1498^{\circ} \mathrm{N} 122.5327^{\circ} \mathrm{W}$, L. Kershaw 7, 2003 (DAO).

This is a rare species in the Territory (McJannet et al. 1995). The specimen cited above is an extension of the known range of about 175 kilometers north of a site adjacent to the Liard River. It is however not far distant from a site on the Norman Wells Pipeline adjacent to the Willowlake River winter road which presumably was introduced (Cody et al. 2000).

Elymus macrourus (Turcz.) Tzvelev (Agropyron sericeum Hitchc.) - MACKENZIE: Hope Bay Area, northeast of Bathurst Inlet, Windy Lake, 68 $03^{\prime} 15^{\prime \prime} \mathrm{N} 106^{\circ} 37^{\prime} 00^{\prime \prime} \mathrm{W}$, K. Reading 310, 29 June 1987 (DAO).

The specimen cited above is an extension of the known range in the Territory of about 750 kilometers east of sites adjacent to the Arctic Coast (Porsild and Cody 1980).

Elymus trachycaulus (Link) Gould ex Shinners ssp. violaceus (Hornem.) A. \& D. Löve (Agropyon trachycaulum (Link) Malte sl.) - MACKENZIE: sand ridge, Coppermine River Area, 67³3'00"N 115 $58^{\prime} 00^{\prime \prime} \mathrm{W}$, K. Reading 97A, 5 Sept. 2002 (DAO) (determined by S. Darbyshire 2002).

The specimen cited above is an extension of the known range of this group (Porsild and Cody 1980) of about 250 kilometers northeast of the east end of Great Bear Lake.

Festuca brachyphylla Schultes - KEEWATIN: Bray Lake, $61^{\circ} 26^{\prime} \mathrm{N} 97^{\circ} 59^{\prime} \mathrm{W}, \mathrm{K}$. Reading 104, 21 June 1990 (DAO).

The specimen cited above is an extension of the known range in the Territory of about 150 kilometers to the northeast of a site in the extreme southwest of the Territory (Porsild and Cody 1980).

Festuca richardsonii Hook. (F. rubra L. ssp. richardsonii (Hook.) Hultén) - MACKENZIE: Hope Bay Area, northeast of Bathurst Inlet, Windy Lake, $68^{\circ} 03^{\prime} 15^{\prime \prime} \mathrm{N}$ 106³7'00"W, K. Reading 312B, 29 June 1987 (DAO). 
The specimen cited above is an extension of the known range in the Territory of about 200 kilometers north of the south end of Bathurst Inlet (Porsild and Cody 1980).

Hierochloe hirta (Schrank) Borbas ssp. arctica (G.) Weim. (H. odorata pro parte sensu Porsild and Cody (1980), Sweet Grass - MACKENZIE: Hope Bay Area, northeast of Bathurst Inlet, Windy Bay, 68 $03^{\prime} 15^{\prime \prime} \mathrm{N}$ 106³7'00"W, K. Reading 317, 29 June 1987 (DAO).

The specimen cited above is an extension of the known range in the Territory of about 540 kilometers northeast of the northeast end of Great Bear Lake (Porsild and Cody 1980).

Muhlenbergia glomerata (Willd.) Trin. - MACKENZIE: mineral spring, Mackenzie Valley pipeline survey, 61 37'17"N 121 30'14"W, L. Kershaw s.n., 8 Aug. 2002 (DAO).

The specimen cited above which is the northernmost yet found in the Territory is an extension of the known range of about 300 kilometers to the northwest of a site adjacent to the Liard River mapped by Porsild and Cody (1980).

Phragmites australis (Cav.) Trin. ex Steud., (P. communis Trin. var. berlandieri (Fourn.) Fern.), Common Reed - MACKENZIE: shallow water about $10 \mathrm{~m}$ from the shore of a large alkaline lake, $61.7617^{\circ} \mathrm{N} 121.0793^{\circ} \mathrm{W}$, L. Kershaw 17, 2003 (DAO).

The specimen cited above from the vicinity of Fort Simpson is from only the second known site in the Territory about 130 kilometers to the northeast in the vicinity of Yohin Lake (Scotter and Cody 1974).

Poa alpina L., Alpine Blue Grass - MACKEnZIE: Coppermine River Area, Camp Peninsula on September (Mouse) Lake, 6706'05"N 115 44'50"W, K. Reading 118, 24 Aug. 2002 (DAO); Hope Bay Area, northeast of Bathurst Inlet, Windy Lake, 68 $03^{\prime} 15^{\prime \prime N} 106^{\circ} 37^{\prime} 00^{\prime \prime W}$, K. Reading 321, 29 June 1987 (DAO).

The first specimen cited above extends the known range in the Territory about 125 kilometers west and the second specimen about 125 kilometers north of a site adjacent to Burnside Landing at latitude $66^{\circ} 51^{\prime} \mathrm{N}$ adjacent to Bathurst Inlet (Cody et al. 1984).

Poa glauca Vahl - MACKENZIE: Hope Bay Area, northeast of Bathurst Inlet, Windy Lake, 6803'15"N 106 37'00"W, K. Reading 313, 29 June 1987 (DAO).

The specimen cited above is an extension of the known range in the Territory of about 170 kilometers from the south end of Bathurst Inlet (Porsild and Cody 1980).

Poa pratensis L. ssp. alpigena (L.) Lindm. (P. alpigena (Fr.) Lindm.) - MACKENZIE: George Lake Camp, $65^{\circ} 53^{\prime} 10^{\prime \prime N} 107^{\circ} 23^{\prime} 00^{\prime \prime W}, K$. Reading 463, 467, 468, 469, 16 Aug. 1988 (DAO); Hope Bay Area, northeast of Bathurst Inlet, Windy Lake, 68 03'05"N 106³7'00"W, K. Reading 316, 319, 29 June 1987 (DAO).

The first location cited above is about 85 kilometers south of sites near latitude $67^{\circ} \mathrm{N}$ reported by Cody et al. (1984). The Windy Lake sites are the northeasternmost yet known from the Territory and are about 130 kilometers north of latitude $67^{\circ} \mathrm{N}$.

Spartina gracilis Trin., Alkali Cord Grass - MACKENZIE: sandbar on north side of river, Willowlake River, $62.7024^{\circ} \mathrm{N} 123.1043^{\circ} \mathrm{W}$, D. Soppet 28,2003 (DAO).
This is a rare species in the Territory (McJannet et al. 1995). The specimen cited above is an extension of the known range of about 240 kilometers northwest of the vicinity of Fort Simpson.

Trisetum spicatum (L.) Richt. - MACKENZIE: George Lake Camp, 65 53'10"N 107²3'8"W, K. Reading 470, 18 Aug. 1988 (DAO); Hope Bay Area, northeast of Bathurst Inlet, Windy Lake, 68 $03^{\prime} 15^{\prime \prime} \mathrm{N} 106^{\circ} 37^{\prime} 00^{\prime \prime W}$, K. Reading 306, 312A, 320, 322, 29 June 1987 (DAO).

The first location cited above is about 85 kilometers south of sites near latitude $67^{\circ} \mathrm{N}$ reported by Cody et al. (1984). The Windy Lake site is the northeasternmost yet known from the Territory and is about 130 kilometers north of latitude $67^{\circ} \mathrm{N}$.

\section{CyPeraceae}

Carex bebbii Olney - MACKENZIE: Mackenzie River Valley pipeline survey, steep boulder strewn stream shore of Mackenzie River near Liard, 61 ${ }^{\circ} 50^{\prime} 53^{\prime \prime} \mathrm{N}$ $121^{\circ} 10^{\prime} 7^{\prime W}$, L. Kershaw s.n., 8 Aug. 2002 (DAO).

Although widespread across much of Canada, Porsild and Cody (1980) knew this rare plant in the Territory from only four locations: near Fort Smith, Fort Good Hope, Fort Simpson and Fort Liard.

Carex canescens L. - KEEWATIN: Griffin Lake, 61 ${ }^{\circ} 16^{\prime} 30^{\prime \prime N} 98^{\circ} 42^{\prime} 00^{\prime \prime W}$, K. Reading 100, 26 July 1990 (DAO).

The specimen cited above is the northernmost yet found in the Territory and is from a site about 60 kilometers northeast of a site mapped by Porsild and Cody (1980).

Carex media R.Br. - KeEwATIN: Griffin Lake, 6116'30"N 9842'00"W, K. Reading 99, 26 July 1990 (DAO).

The specimen cited above is the first known from this Territory. It is from a site about 85 kilometers northeast of a site in the province of Manitoba, just south of latitude $60^{\circ} \mathrm{N}$ (Porsild and Cody 1980).

Carex nardina Fries - MACKENZIE: Hope Bay Area, northeast of Bathurst Inlet, Windy Lake, 68 $03^{\prime} 15^{\prime \prime} \mathrm{N}$ 106³7'00"W, K. Reading 301, 14 July 1987 (DAO).

The specimen cited above is an extension of the known range in the Territory of about 170 kilometers northeast of a location cited by Cody et al. (1984) and is the northeasternmost yet known in the Territory.

Carex rariflora (Wahlenb.) Sm. - KEEWATIN: west of Imikula Lake, 62 $10^{\prime} 00^{\prime \prime} \mathrm{N} 97^{\circ} 40^{\prime} 20^{\prime \prime} \mathrm{W}$, K. Reading 397, 10 Aug. 1983 (DAO).

The specimen cited above is an extension of the known range in the Territory of about 80 kilometers inland from sites adjacent to the Hudson Bay coast (Porsild and Cody 1980).

Carex rotundata Wahl. - KeEWATIN: SY area, $62^{\circ} 12^{\prime} 20^{\prime \prime N} 97^{\circ} 53^{\prime} 00^{\prime \prime W}$, K. Reading 219, 19 July 1984 (DAO).

The specimen cited above is an extension of the known range in the Territory of about 80 kilometers northeast of a site in the extreme south mapped by Porsild and Cody (1980).

Carex scirpoidea Michx. - MACKENZIE: sand flats, Coppermine River area, 6706'05"N 11544'50"W, K. Reading 15A, 8 Sept. 2002 (DAO); Hope Bay Area, northeast of Bathurst Inlet, Windy Lake, $68^{\circ} 03^{\prime} 15^{\prime \prime} \mathrm{N}$ 
$106^{\circ} 37^{\prime} 00^{\prime \prime W}$, K. Reading 287, 15 July 1987 (DAO);

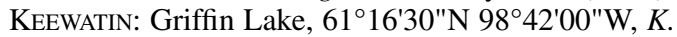
Reading 226, 26 July 1990 (DAO).

The first specimen cited above is from a site midway between Coppermine and the south end of Bathurst Inlet (Porsild and Cody 1980). The second specimen is an extension of the known range in the Territory of about 170 kilometers northeast of the south end of Bathurst Inlet and is the northeasternmost yet known in the Territory. The third specimen is an extension of about 100 kilometers northeast of the southwesternmost previously known site in Keewatin (Porsild and Cody 1980).

Carex subspathacea Wormskj. - MACKENZIE: Hope Bay Area, northeast of Bathurst Inlet, Windy Lake, $68^{\circ} 03^{\prime} 15^{\prime \prime N} 106^{\circ} 37^{\prime} 00^{\prime W}$, K. Reading 283, 15 July 1987 (DAO).

The specimen cited above of this rare northern species is from a site about 170 kilometers northeast of the south end of Bathurst Inlet (Porsild and Cody 1980) and is the easternmost yet found in the Territory.

Carex supina Wahl. ssp. spaniocarpa (Steud.) Hultén - MACKENZIE: Hope Bay Area, northeast of Bathurst Inlet, Windy Lake, 6803'15"N 106 37'00"W, K. Reading 311, 29 June 1987 (DAO).

The specimen cited above is from a site about 170 kilometers northeast of the south end of Bathurst Inlet (Porsild and Cody 1980) and is the northeasternmost yet found in the Territory.

Carex vaginata Tausch - MACKENZIE: Hope Bay Area, northeast of Bathurst Inlet, Roberts Lake, 68 ${ }^{\circ} 10^{\prime} 30^{\prime \prime} \mathrm{N}$ 106³3'00"W, K. Reading 330, 4 Aug. 1987 (DAO).

The specimen cited above is an extension of the known range in the Territory of about 150 kilometers northeast of a site near Burnside Landing adjacent to Bathurst Inlet (Cody et al. 1984).

Eriophorum angustifolium Honckn. - MACKENZIE: Hope Bay Area, northeast of Bathurst Inlet, Windy Lake, 6803'15"N 106³7'00"W, K. Reading 202, 15 July 1987 (DAO); Hope Bay Area, northeast of Bathurst Inlet, Roberts Lake, 68 ${ }^{\circ} 10^{\prime} 30^{\prime \prime N} 106^{\circ} 33^{\prime} 00^{\prime \prime} \mathrm{W}$, K. Reading 261, 1 Aug. 1987 (DAO).

The specimens cited above are a northern extension of the known range in the Territory of about 170 kilometers north of a site east of the south end of Bathurst Inlet (Porsild and Cody 1984).

Eriophorum callitrix Cham. - MACKENZIE: George Lake Camp, 65 $53^{\circ} 12^{\prime \prime} \mathrm{N} 107^{\circ} 23^{\prime} 8 " \mathrm{~W}$, K. Reading 465, 18 Aug. 1988 (DAO).

The specimen cited above is an extension of the known range in the Territory of about 80 kilometers south of the south end of Bathurst Inlet (Porsild and Cody 1980).

Eriophorum triste (Th. Fr.) Hadac \& Löve - MACKENZIE: Hope Bay Area, northeast of Bathurst Inlet, Windy Lake, 6803'15"N 106³7'00"W, K. Reading 286, 5 July 1987 (DAO).

The specimen cited above of this circumpolar arcticalpine species is an extension of the known range in the Territory of about 500 kilometers northeast of a site adjacent to the east end of Great Bear Lake. Adjacent to the Arctic
Coast it is known about 400 kilometers to the west and it is also known from Victoria Island (Porsild and Cody 1980).

Eriophorum vaginatum L. - MACKENZIE: Hope Bay Area, northeast of Bathurst Inlet, Windy Lake, $68^{\circ} 03^{\prime} 15^{\prime \prime N} 106^{\circ} 37^{\prime} 00^{\prime \prime W}, K$. Reading 285, 5 July 1987 (DAO).

The specimen cited above is an extension of the known range in the Territory of about 150 kilometers northeast of sites adjacent to the middle of Bathurst Inlet (Cody et al. 1984).

Eriophorum viridi-carinatum (Engelm.) Fern. - KEEWATIN: SY area, $62^{\circ} 12^{\prime} 30^{\prime \prime} \mathrm{N} 97^{\circ} 55^{\prime} 00^{\prime \prime} \mathrm{W}$, K. Reading 252, 17 Aug. 1984 (DAO).

This species is new to Continental District of Keewatin. It is known to the west in the District of Mackenzie about 625 kilometers away at the east end of Great Slave Lake and to the southwest in Saskatchewan about 475 kilometers away just south of the provincial border (Porsild and Cody 1980).

Rhynchospora alba (L.) Vahl, White Beak-rush - MACKENZIE: $61.9954^{\circ} \mathrm{N} 121.5027^{\circ} \mathrm{W}$, L. Kershaw 20, 2003 (DAO).

This is a rare species in the Northwest Territories (McJannet et al. 1995) known from a single site near Hearst Lake (Cody and Talbot 1978) south of the east end of Great Slave Lake. The specimen cited above is from a site about 150 kilometers to the northwest.

Scirpus caespitosus L. ssp. austriacus (Pallas) Asch. \& Graebn. - KeEwatin: east of Pebble Beach Lake, south of Yathkyed Lake, $62^{\circ} 22^{\prime} 00^{\prime \prime} \mathrm{N} 97^{\circ} 28^{\prime} 00^{\prime \prime W}, K$. Reading 178, 10 July 1985 (DAO).

The specimen cited above is from a site midway between sites near the southern territories border and latitude $64^{\circ} \mathrm{N}$ (Porsild and Cody 1980).

Scirpus rollandii Fern. - MACKENZIE: Mackenzie River Valley pipeline survey, mineral rich site near

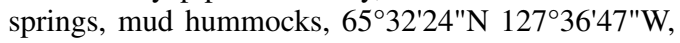
L. Kershaw s.n., 1 Aug. 2002 (DAO); hundred plus plants in calcareous area where stream widens and pools on flat area before flowing into mineral lake, Wrigley area, $62.7307^{\circ} \mathrm{N} 123.1098^{\circ} \mathrm{W}$, D. Soppet $26 A$, 2003 (DAO).

McJannet et al. (1995) knew this rare species in the Territory from only four localities, one near the northwest end of Great Slave Lake and three in the Mackenzie Mountains. The first specimen cited above is from a site northeast of the previously northernmost site in the mountains. The second specimen is from a site midway between the Mackenzie Mountain site and a site west of the north arm of Great Slave Lake.

\section{JUNCACEAE}

Juncus arcticus Willd. - MACKENZIE: Coppermine River Area, sandy lakeshore, $67^{\circ} 06^{\prime} 08^{\prime \prime} \mathrm{N} 115^{\circ} 44^{\prime} 50^{\prime \prime} \mathrm{W}, K$. Reading 15B, 15 Aug. 2002 (DAO); KeEWATIN: Big Bird Lake, 62 $17^{\prime} 30^{\prime \prime N} 97^{\circ} 38^{\prime} 00^{\prime \prime W}, K$. Reading 180, 25 June 1985 (DAO).

The first specimen cited above is from a site about 100 kilometers west of Bathurst Inlet. The second specimen is from a site midway between a site adjacent to the Manitoba border west of Hudson Bay and a site about latitude $63^{\circ} 30^{\prime} \mathrm{N}$ east of longitude $100^{\circ} \mathrm{W}$ (Porsild and Cody 1980). 
Juncus castaneus Smith ssp. castaneus - MACKENZIE: Hope Bay Area, northeast of Bathurst Inlet, Roberts Lake, 68 $10^{\prime} 30^{\prime \prime N} 106^{\circ} 33^{\prime} 00^{\prime \prime} \mathrm{W}, K$. Reading 329, 4 Aug. 1987 (DAO); KeEwATIN: No-camp Lake, south of Yathkeyed Lake, 62 $22^{\prime} 00^{\prime \prime} \mathrm{N} 97^{\circ} 27^{\prime} 30^{\prime \prime W}, K$. Reading 201, 21 July 1985 (DAO); Big Bird Lake, $62^{\circ} 17^{\prime} 30^{\prime \prime N} 97^{\circ} 38^{\prime} 00^{\prime \prime} \mathrm{W}, K$. Reading 181, 25 June 1985 (DAO).

The first specimen cited above is an extension of the known range in the Territory of about 200 kilometers northeast of the south end of Bathurst Inlet. The second and third specimens are from sites about 125 kilometers north of a site in the interior of the District of Keewatin mapped by Porsild and Cody (1980).

Juncus stygius L. ssp. americanus (Buch.) Hultén, Bog Rush - MackEnZIE: Mackenzie River Valley pipeline survey, sandy shoreline of creek, 61'19'27"N 120 50'21"W, L. Kershaw s.n., 3 Aug. 2002 (DAO); in graminoid/shrub fen in lower wet spots, $60.6383^{\circ} \mathrm{N}$ $120.3463^{\circ} \mathrm{W}$, D. Soppet 9, 17 Aug. 2003 (DAO).

The first specimen cited above from south of Fort Simpson is only the fourth known in the Territory. McJannet et al. (1995) knew it from just north of latitude $60^{\circ} \mathrm{N}$ from south of the east and west ends of Great Slave Lake and adjacent to Hudson Bay.This species was first recorded in the Territory by J. W. Thieret (1959) on the basis of a specimen collected by Thieret and Reich (1964) from among sedges at foot of "hummock island" in marly lake at mile 44 $\frac{1}{2}$ EnterpriseMackenzie River Highway, about 215 kilometers east of the specimens cited above.

Juncus triglumis L. ssp. albescens (Lange) Hultén ( $J$. albescens (Lange) Fern.) - MACKENZIE: Coppermine River Area, 67 $06^{\prime} 05^{\prime \prime} \mathrm{N} 115^{\circ} 44^{\prime} 50^{\prime \prime} \mathrm{W}, K$. Reading 297, 3 Sept. 2002 (DAO).

The specimen cited above is from a site midway between the south end of Bathurst Inlet and sites at the east end of Great Bear Lake (Porsild and Cody 1980).

Luzula wahlenbergii Rupr. - MACKENZIE: George Lake Camp, 65 $55^{\prime} 10^{\prime \prime} \mathrm{N} 107^{\circ} 23^{\prime} 00^{\prime \prime} \mathrm{W}$, K. Reading 466, 18 Aug. 1988 (DAO).

The specimen cited above is from a site about 175 kilometers west of a site at about $101^{\circ} \mathrm{W}$ longitude just south of latitude $66^{\circ} \mathrm{N}$ (Porsild and Cody 1980).

\section{LILIACEAE}

Tofieldia coccinea Richards. - KEEWATIN: Kazan Falls, 634' $03^{\prime \prime N} 95^{\circ} 51^{\prime} 30^{\prime \prime} \mathrm{W}, K$. Reading 348, 30 Aug. 1982 (DAO).

The specimen cited above is an extension of the known range in the Territory of about 150 kilometers east of specimens adjacent to longitude $100^{\circ} \mathrm{W}$ (Porsild and Cody 1980).

Tofieldia pusilla (Michx.) Pers. - KeEWATIN: south of Bissett Lake, 6343'00"N 95¹8'00"W, K. Reading 347, 22 July 1982 (DAO).

The specimen cited above is from a site about 150 kilometers east of a site just east of longitude $100^{\circ} \mathrm{W}$ (Porsild and Cody 1980).

\section{SALICACEAE}

Salix alaxensis (Anderss.) Cov. - MACKENZIE: sand flat below esker, Coppermine River Area, 67 33'00"N 11558'00"W, K. Reading 308, 5 Sept. 2002 (DAO) (determined by G. Argus).

The specimen cited above is from a site midway between the south end of Bathurst Inlet and the vicinity of Coppermine (Porsild and Cody 1980).

Salix arctica Pallas, Arctic Willow - MACKENZIE: Hope Bay Area, northeast of Bathurst Inlet, Windy Lake, 68 03'15"N 106 37'00"W, K. Reading 442, 7 July 1987 (DAO); Roberts Lake, 68¹0'30"N 106³3'00"W, K. Reading 278, 24 June 1987, 250, 4 Aug. 1987, K. Reading 274, 10 Aug. 1987 (DAO) (determined by G. Argus).

The four specimens cited above are a northeast extension of the known range in the Territory of about 170 kilometers from a site at the southern end of Bathurst Inlet (Porsild and Cody 1980).

Salix arctica $\times$ glauca - MACKENZIE: Hope Bay Area, northeast of Bathurst Inlet, Windy Lake, 68 $03^{\prime} 15^{\prime \prime} \mathrm{N}$ $106^{\circ} 37^{\prime} 00^{\prime \prime W, ~ K . ~ R e a d i n g ~ 448, ~ 449, ~ 450, ~} 7$ July 1987, 14 July 1987 (DAO) (determined by G. Argus).

This putative hybrid was not known to Porsild and Cody (1980).

Salix arctophila Cockerell - KEEWATIN: southwest of Big Bird Lake, south of Yathkyed Lake, 62 $16^{\prime} 50^{\prime \prime} \mathrm{N}$ 9741'00"W, K. Reading 144, 28 June 1985 (DAO); southwest of Big Bird Lake, 62 $17^{\prime} 00^{\prime \prime} \mathrm{N} 97^{\circ} 40^{\prime} 00^{\prime \prime} \mathrm{W}$, $K$. Reading 30, 28 June 1985 (DAO); southwest of No-camp Lake, south of Yathkyed Lake, 62 $22^{\prime} 40^{\prime \prime} \mathrm{N}$ 97²7'30"W, K. Reading 436, 11 July 1985 (DAO); Camp 2, 61 $21^{\circ} 00^{\prime \prime} \mathrm{N} 97^{\circ} 53^{\prime} 30^{\prime \prime W}, K$. Reading 447, 7 July 1990 (DAO) (determined by G. Argus).

The specimens cited above are from sites midway between the Hudson Bay Coast and a site just east of longitude $100^{\circ} \mathrm{W}$ (Porsild and Cody 1980).

Salix fuscescens Anderss. - KeEWATIN: Big Bird Lake, $62^{\circ} 18^{\prime} 00^{\prime \prime N} 97^{\circ} 39^{\prime} 00^{\prime \prime W}, K$. Reading 36, 25 June 1985 (DAO); Washaneepisuki Lake, 62 $12^{\prime} 30^{\prime \prime} \mathrm{N} 97^{\circ} 52^{\prime} 00^{\prime \prime} \mathrm{W}$, $K$. Reading 141, 17 July 1984 (DAO); north of No-camp Lake, 62²2'15"N 97²7'10"W, K. Reading 435, 11 July 1985 (DAO) (determined by G. Argus).

The specimens cited above are from sites midway between the Hudson Bay Coast and a site just east of longitude $100^{\circ} \mathrm{W}$ (Porsild and Cody 1980).

Salix glauca L. var. acutifolia (Hook.) Schneid., Blue-green Willow - MACKENZIE: Hope Bay Area, northeast of Bathurst Inlet, Roberts Lake, 68 $10^{\prime} 30^{\prime \prime} \mathrm{N}$ 106 33'00"W, K. Reading 276, 10 Aug. 1987 (DAO) (determined by G. Argus).

The specimen cited above is an extension of the known range in the Territory of about 170 kilometers northeast of the south end of Bathurst Inlet and is the northeasternmost site in the Territory (Porsild and Cody 1980).

Salix glauca L. ssp. callicarpaea (Trautv.) Böcher KeEWATIN: Bray Lake, 6126'N 9759'W, K. Reading 451, 21 June 1990 (DAO); Washaneepisuki Lake, $62^{\circ} 12^{\prime} 30^{\prime \prime N} 97^{\circ} 52^{\prime} 00^{\prime \prime W}$, K. Reading 148, 17 July 1984 
(DAO); north of No-camp Lake, south of Yathkyed Lake, $62^{\circ} 22^{\prime} 15^{\prime \prime} \mathrm{N} 97^{\circ} 28^{\prime} 10^{\prime \prime} \mathrm{W}, \mathrm{K}$. Reading 138, 16 July 1985 (DAO); north of No-camp Lake south of Yathkyed Lake, $62^{\circ} 22^{\prime} 00^{\prime \prime N} 97^{\circ} 30^{\prime} 05^{\prime \prime} \mathrm{W}$, K. Reading 139, 22 July 1985 (DAO) (determined by G. Argus).

This subspecies was known in northeastern North America from Greenland, Labrador, Newfoundland and Quebec (specimens in DAO determined by G. Argus). The specimens cited above extend the known range into central southern District of Keewatin.

Salix myrtillifolia Anderss., Blueberry Willow - KeEWATIN: Bray Lake, $61^{\circ} 26^{\prime} \mathrm{N} 97^{\circ} 59^{\prime} \mathrm{W}, \mathrm{K}$. Reading 444, 21 June 1990 (DAO) (determined by G. Argus).

This species is new to mainland District of Keewatin. The nearest site mapped by Porsild and Cody (1980) was in northwestern Manitoba about 340 kilometers to the southwest and to the west in the District of Mackenzie it is common west of about longitude $106^{\circ} \mathrm{W}$.

Salix planifolia Pursh, Tea-leaf Willow - MACKENZIE: Hope Bay Area, northeast of Bathurst Inlet, Windy Lake, 68 $03^{\prime} 15^{\prime \prime}$ 106 $37^{\prime} 00^{\prime \prime W}$, K. Reading 446, 452, 1 and 7 July 1987 (DAO); KEEWATIN: Washaneepisuki Lake, $62^{\circ} 12^{\prime} 30^{\prime \prime} \mathrm{N} 97^{\circ} 52^{\prime} 00^{\prime \prime} \mathrm{W}, K$. Reading 142, 15 July 1984 (DAO); Big Bird Lake, 62¹7'30"N $97^{\circ} 38^{\prime} 00^{\prime \prime W}$, K. Reading 437, 25 June 1985 (DAO); 62²0'00"N 97²2'00"W, K. Reading 32, 16 July 1985 (DAO); Pebble Beach Lake south of Yathkyed Lake,

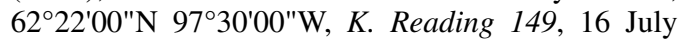
1985 (DAO) (determined by G. Argus).

The Windy Lake specimen cited above is an extension of the known range in the District of Mackenzie of about 170 kilometers from sites adjacent to Bathurst Inlet south of latitude $67^{\circ} \mathrm{N}$ reported by Cody et al. (1984). The District of Keewatin sites are midway between the Hudson Bay Coast and about longitude $98^{\circ} \mathrm{W}$.

Salix reticulata L., Net-veined Willow - MACKENZIE: Hope Bay Area, northeast of Bathurst Inlet, Roberts Lake, 68 10'30”'N 106³3'00"W, K. Reading 279, 22 July 1987 (DAO); KeEWATIN: Camp 2, 61 $21^{\circ} 00^{\prime N} \mathrm{~N}$ 9753'31"W, K. Reading 439, 7 July 1990 (DAO); Washaneepisuki Lake, west of Imikula Lake, 62¹2'30"N 9752'00"W, K. Reading 145, 3 July 1984 (DAO); Pebble Beach Lake south of Yathkyed Lake,

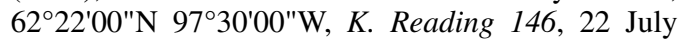
1985 (DAO) (determined by G. Argus).

The first specimen cited above is an extension of the known range in the District of Mackenzie of about 170 kilometers northeast of a site at the south end of Bathurst Inlet (Porsild and Cody 1980). The District of Keewatin specimens are from sites midway between the Hudson Bay Coast and longitude $101^{\circ} \mathrm{W}$ (Porsild and Cody 1980).

Salix richardsonii Hook. (S. lanata L. ssp. richardsonii (Hook.) Hultén, Richardson's Willow - MACKENZIE: Hope Bay Area, northeast of Bathurst Inlet, Windy Lake, 68 $03^{\prime} 15^{\prime \prime} \mathrm{N} 106^{\circ} 37^{\prime} 00^{\prime \prime} \mathrm{W}$, K. Reading 441, 445, 7 July 1987 (DAO); Hope Bay Area, northeast of Bathurst Inlet, Roberts Lake, 68 $10^{\prime} 30^{\prime \prime} \mathrm{N}$ 106³3'W, K. Reading 275, 10 Aug. 1987 (DAO); KeEwATIN: Big Bird Lake, south of Yathkyed Lake, $62^{\circ} 17^{\prime} 30^{\prime \prime N} 97^{\circ} 38^{\prime} 00^{\prime \prime W}$, K. Reading 150, 25 June 1985 (DAO); Pebble Beach Lake south of Yathkyed Lake, 62 $22^{\prime} 00^{\prime \prime N} 97^{\circ} 52^{\prime} 00^{\prime \prime W}, K$. Reading 151, 11 June 1985 (DAO) (determined by G. Argus).

The Mackenzie specimens cited above are an extension of the known range in the Territory of about 170 kilometers northeast of a site in the vicinity of Burnside Landing adjacent to Bathurst Inlet. The Keewatin specimens extend the known range in the Territory about 250 kilometers north from a site adjacent to the Manitoba border (Porsild and Cody 1980).

Salix rotundifolia Trautv. ssp. rotundifolia, Round-leaf Willow - MACKENZIE: Mackenzie Mountains, limestone, stoney tundra slope, 17 miles NW Little Divide Lake, $63^{\circ} 17^{\prime} \mathrm{N} 128^{\circ} 17^{\prime} \mathrm{W}$, W. J. Cody 16633, 26 July 1967 (DAO); Mackenzie Mountains, in deep moss on granitic mountain, 5 miles SE of O'Grady Lake, $62^{\circ} 57^{\prime} \mathrm{N} 128^{\circ} 58^{\prime} \mathrm{W}$, W. J. Cody 16750, 27 July 1967 (DAO); Mackenzie Mountains, 10 miles NE of O'Grady Lake, $63^{\circ} 05^{\prime} \mathrm{N} 128^{\circ} 50^{\prime} \mathrm{W}$, W. J. Cody 16889 , 29 July 1967 (DAO) (determined by G. Argus).

This willow was not included in the Vascular Plants of Continental Northwest Territories (Porsild and Cody 1980). It was however described and mapped by Argus in his Guide to the identification of willows in Alaska, the Yukon Territory and adjacent regions (Argus 2001). The specimens cited above are the basis for the maps in this treatment.

Salix sphenophylla A.K. Skvort. - MACKENZIE: delta low centre polygons, south of Big Lake, $69.3652^{\circ} \mathrm{N}$ $134.899^{\circ} \mathrm{W}, D$. Bush 25, 2003 (DAO) (determined by G. Argus).

This species was reported as new to the Northwest Territories by McJannet et al. (1995) on the basis of a specimen collected by E. Kutke at Nig, 74 miles north of Inuvik (DAO). The specimen cited above is the second record for the Territory.

\section{POLYGONACEAE}

Polygonum viviparum L., Bistort - KeEWATIN: 6208'50"N 9753'00"W, K. Reading 37, 15 July 1984 (DAO); 62 $12^{\prime} 00^{\prime \prime} \mathrm{N} 97^{\circ} 52^{\prime} 00^{\prime \prime} \mathrm{W}, K$. Reading 51, 3 July 1984 (DAO).

The specimens cited above are from sites in the southern District of Keewatin about 150 kilometers east of a site just east of longitude $100^{\circ} \mathrm{W}$ (Porsild and Cody 1980 ).

\section{Chenopodiaceae}

Chenopodium dessicatum A. Nels. (C. leptophyllum Nutt.), Narrow-leaved Goosefoot - MACKENZIE: middle of open, revegetated sandy slope, $61.7441^{\circ} \mathrm{N} 121.1543^{\circ} \mathrm{W}$, L. Kershaw 5, 2003.

Porsild and Cody (1980) reported C. leptophyllum as "In the Northwest Territories thus far known only from a Richardson specimen collected a Century and a half ago, at Fort Franklin, where it was surely an ephemeral introduction". The specimen cited above is from a site about half way between Fort Franklin and the west end of Lake Athabasca and may also be an ephemeral introduction. 


\section{CARYOPHYLLACEAE}

Cerastium alpinum L. - MACKENZIE: siksik mound, Coppermine River Area, 67³2'30"N 11601'30"W, K. Reading 77, 29 Aug. 2002 (DAO); Hope Bay Area, northeast of Bathurst Inlet, Roberts Lake, 68 $10^{\prime} 30^{\prime \prime} \mathrm{N}$ 106³3'00"W, K. Reading 241, 7 Aug. 1987 (DAO).

The first specimen cited above is an extension of the known range in the Territory of about 250 kilometers west of a site at the south end of Bathurst Inlet. The second specimen is an extension of the known range about 170 kilometers to the northeast (Porsild and Cody 1980).

Cerastium beeringianum Cham. \& Schlecht. - MACKENZIE: Hope Bay Area, northeast of Bathurst Inlet, Roberts Lake, 68 $10^{\prime} 30^{\prime \prime N} 106^{\circ} 33^{\prime} 00^{\prime \prime W}$, K. Reading 214, 10 Aug. 1987 (DAO).

The specimen cited above is an extension of the known range in the Territory of about 170 kilometers to the northeast of the south end of Bathurst Inlet (Porsild and Cody 1980).

Minuartia biflora (L.) Schinzl. \& Thell. - KEEWATIN: 11 miles south of east end of Bissett Lake, 6339'10"N 95¹0'00"W, K. Reading 370, 18 Aug. 1982 (DAO).

The specimen cited above is an extension of the known range in the Territory of about 100 kilometers north of a site in the southern half of the Territory (Porsild and Cody 1980).

Minuartia rossii (R.Br.) Graebn. - KEEWATIN: Bissett Creek, 6346'00"N 95³0'00"W, K. Reading 368, 25 July 1982 (DAO).

The specimen cited above is a westerly extension into central mainland Keewatin of 500 kilometers from sites on Southampton Island. To the north it is known from sites adjacent to the Arctic Coast and the Arctic Islands (Porsild and Cody 1980).

Minuartia rubella (Wahlenb.) Graebn. - KEEWATIN: south of east end of Bissett Lake, 64\%40'30"N 95¹2'00"W, K. Reading 371, 20 Aug. 1982 (DAO).

The specimen cited above is midway between a site adjacent to the Hudson Bay Coast and about $65^{\circ} \mathrm{N} 98^{\circ} \mathrm{W}$ (Porsild and Cody 1980).

Minuartia yukonensis Hultén - MACKENZIE: east bank of Mackenzie River, $68^{\circ} 52.1^{\prime} \mathrm{N} 134^{\circ} 29.8^{\prime} \mathrm{W}$, J.V. Matthews s.n., 4 Aug. 1983 (DAO); Mackenzie River Valley pipeline survey, Parson's Lake area, 68 59'05"N 13330'59"W, J. Lancaster s.n., 5 Aug. 2002 (DAO); Ya Ya esker, 69.2093 ${ }^{\circ} \mathrm{N} 134.5636^{\circ} \mathrm{W}, J$. Lancaster 12A, 9 July 2003 (DAO).

Porsild and Cody (1980) knew this Amphi-Beringian species in the Continental Northwest Territories only as far east as the east slope of the Richardson Mountains west of the Mackenzie Delta. The specimens cited above extend the known distribution eastward to part of the Mackenzie River and eastward further to Parson's Lake about 100 kilometers to the northeast.

Sagina caespitosa (J. Vahl) Lge. - KeEwATIN: TK

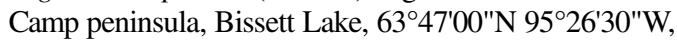
$K$. Reading 367, 17 July 1982 (DAO).

The specimen cited above is an extension of the known range in the Territory of about 125 kilometers east of the northernmost site mapped by Porsild and Cody (1980).
Silene walensis (Rupr.) Bouquet (Melandrium apetalum (L.) Fenzl ssp. arcticum (Fr.) Hultén) - MACKENZIE: Hope Bay Area, northeast of Bathurst Inlet, Roberts Lake, 68 $10^{\prime} 30^{\prime \prime} \mathrm{N} 106^{\circ} 33^{\prime} 00^{\prime \prime} \mathrm{W}, \mathrm{K}$. Reading 267, 30 July 1987 (DAO); KEEWATIN: wet tundra rills, north of 30-mile lake, $63^{\circ} 46^{\prime} 00^{\prime \prime} \mathrm{N} 96^{\circ} 07^{\prime} 00^{\prime \prime} \mathrm{W}, K$. Reading 351, 31 July 1981 (DAO).

The first specimen cited above is an extension of the known range in the Territory of about 170 kilometers northeast of a site at the south end of Bathurst Inlet (Porsild and Cody 1980). The Keewatin site is midway between the Hudson Bay Coast and sites just east of longitude $100^{\circ} \mathrm{W}$.

Stellaria calycantha (Ledeb.) Bong. - KEEWATIN: Griffin Lake, $61^{\circ} 19^{\prime} \mathrm{N} 98^{\circ} 46^{\prime} \mathrm{W}, K$. Reading 340, $10 \mathrm{Aug}$. 1990 (DAO); 62 $11^{\prime} \mathrm{N} 97^{\circ} 52^{\prime} \mathrm{W}, K$. Reading 61, 19 July 1984 (DAO); SY area, 62 $12^{\prime} 10^{\prime \prime} \mathrm{N} 97^{\circ} 53^{\prime} 00^{\prime \prime} \mathrm{W}$, $K$. Reading 136, 5 Aug. 1984 (DAO).

The specimens cited above extend the known range in the Territory about 180 kilometers north of a site north of the Manitoba border (Porsild and Cody 1980).

Stellaria longipes Goldie s.1. - MACKENZIE: scarp foot, Coppermine River Area, $67^{\circ} 07^{\prime} \mathrm{N} 115^{\circ} 05^{\prime} \mathrm{W}$, K. Reading 89, 28 Aug. 2002 (DAO); KeEWATIN: east of Kazan

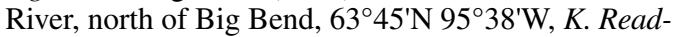
ing 399B, 8 Aug. 1983 (DAO); south of Whale Lake, 634' $\mathrm{N} 96^{\circ} 06^{\prime} \mathrm{W}, K$. Reading 369, 21 Aug. 1982 (DAO).

The first specimen cited above extends the known distribution about 250 kilometers west of the Burnside Landing area adjacent to Bathurst Inlet (Cody et al. 1984). The Keewatin specimens extend the known range to the northeast about 250 kilometers to the central area of Keewatin (Porsild and Cody 1980).

\section{NYMPHAEACEAE}

Nymphaea tetragona Georgi ssp. leibergii (Morong) Porsild - MACKENZIE: small lake in Camsell Ferry infrastructure midway on west shore of lake behind beaverlodge, $62.1567^{\circ} \mathrm{N} 122.4908^{\circ} \mathrm{W}$, L. Kershaw 15, 2003 (DAO).

This rare plant in the Territory was first reported by A. E. Porsild (1939) on the basis of a collection by E. A. Preble from an island of the Simpson group 40 miles northeast of Resolution, Great Slave Lake. The specimen cited above is from a site about 425 kilometers to the west.

\section{RANUNCULACEAE}

Anemone parviflora Michx. - MACKENZIE: Hope Bay Area, northeast of Bathurst Inlet, Windy Lake, 68 03'15"N 106 37'00"W, K. Reading 296, 14 July 1987 (DAO); KeEWATIN: Big Bird Lake, 62 $18^{\circ} 00^{\prime \prime} \mathrm{N}$ 97³7'40"W, K. Reading 440, 28 June 1985 (DAO).

The first specimen cited above is an extension of the known range in the Territory of about 100 kilometers northeast of a site adjacent to Bathurst Inlet (Porsild and Cody 1980). The second specimen is an eastward extension of about 80 kilometers from a site just east of longitude $100^{\circ} \mathrm{W}$.

Anemone richardsonii Hook. - KEEWATIN: creek into southwest corner of Pebble Beach Lake, 62 21'50"N $97^{\circ} 22^{\prime} 00^{\prime \prime W}$, K. Reading 443, July 1985 (DAO). 
The specimen cited above is encircled by six other sites in the southern half of the Territory (Porsild and Cody 1980).

Caltha natans Pall., Floating Marsh-marigold - KEEWATIN: northwest corner of Bissett Lake, 63⒋ $48^{\prime} 00^{\prime \prime} \mathrm{N}$ 95²7'00"W, K. Reading 345, 8 Aug. 1983 (DAO).

This species is rare in the Continental District of Keewatin. The specimen cited above is an extension of the known range in the Territory of about 375 kilometers to the north and northeast from two sites in the south (Porsild and Cody 1980).

Caltha palustris L. var. arctica (R.Br.) Hultén, Marshmarigold - MACKENZIE: Hope Bay Area, northeast of Bathurst Inlet, Roberts Lake, 68 $10^{\prime} 30^{\prime \prime} \mathrm{N} 106^{\circ} 33^{\prime} 00^{\prime \prime W}$, K. Reading 273, 24 July 1987 (DAO).

The specimen cited above is an extension of the known range in the Territory of about 175 kilometers from the south end of Bathurst Inlet (Porsild and Cody 1980).

Ranunculus aquatilis L. var. eradicatus Laest., White Water Buttercup - MACKENZIE: lake bottom, Coppermine River Area, 67³2'50"N 116 $13^{\prime} 00^{\prime \prime} \mathrm{W}$, K. Reading 75, 23 Aug. 2002 (DAO).

The specimen cited above is from a site midway between the south end of Bathurst Inlet and the east end of Great Bear Lake (Porsild and Cody 1980).

Ranunculus sabinei R.Br. - KeEWATIN: Fly Camp 3, 6553'N 98³4'W, S. Smith 204, 20 July 1983 (DAO);

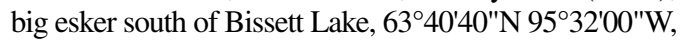
K. Reading 373, 16 Aug. 1981 (DAO); 62 $11^{\circ} 00^{\prime \prime} \mathrm{N}$ 9755'00"W, K. Reading 60, 13 July 1984 (DAO).

The specimens cited above extend the known distribution in the Territory south of the Arctic Coast into central District of Keewatin (Porsild and Cody 1980).

Ranunculus xspitzbergensis (Nath.) Hadac - KEEWATIN: This hybrid of Ranunculus lapponicus $\times R$. pallasii was reported by Cody et al. (1988) on the basis of a specimen collected by K. Reading at Jaeger Creek, $62^{\circ} 11^{\prime} 20^{\prime \prime} \mathrm{N} 97^{\circ} 53^{\prime} 00^{\prime \prime} \mathrm{W}$ in 1984 and also from northern Quebec.

\section{PAPAVERACEAE}

Papaver radicatum Rottb. - MACKENZIE: Hope Bay Area, northeast of Bathurst Inlet, Roberts Lake, $68^{\circ} 10^{\prime} 30^{\prime \prime} \mathrm{N} 106^{\circ} 33^{\prime} 00^{\prime \prime} \mathrm{W}, K$. Reading 251, 4 Aug. 1987 (DAO).

The specimen cited above is an extension of the known range in the Territory to the northeast of a site about 170 kilometers from the south end of Bathurst Inlet (Porsild and Cody 1980).

\section{BRASSICACEAE (CRUCIFERAE)}

Braya glabella Richardson - MACKENZIE: Hope Bay Area, northeast of Bathurst Inlet, Roberts Lake, 68 $10^{\prime} 30^{\prime \prime N} 106^{\circ} 33^{\prime} 00^{\prime \prime W}, K$. Reading 485, 12 Aug. 1987 (DAO) (determined by G.A. Mulligan).

The specimen cited above is an extension of the known range in the Territory of about 170 kilometers northeast of the south end of Bathurst Inlet (Porsild and Cody 1980) and is the northeasternmost site yet known in the Territory.
Braya humilis (C.A. Mey.) Robins. - MACKEnZIE: Hope Bay Area, northeast of Bathurst Inlet, Roberts Lake, 68 $10^{\prime} 30^{\prime \prime N} 106^{\circ} 33^{\prime} 00^{\prime \prime} \mathrm{W}$, K. Reading 486, 13 Aug. 1987 (DAO) (determined by G. A. Mulligan).

The specimen cited above is an extension of the known range in the Territory of about 170 kilometers northeast of a site west of Bathurst Inlet and is the northeasternmost yet known in the Territory (Porsild and Cody 1980). To the north it is known on Victoria Island.

Cardamine bellidifolia L. - MACKENZIE: dolomite ridge, Coppermine River area, 67 $07^{\prime} 00^{\prime \prime} \mathrm{N} 115^{\circ} 45^{\prime} 00^{\prime \prime} \mathrm{W}$, K. Reading 91, 28 Aug. 2002 (DAO); KeEWATIN: $62^{\circ} 10^{\prime} 30^{\prime \prime N} 97^{\circ} 59^{\prime} 00^{\prime \prime W}, K$. Reading 474, 17 Aug. 1984 (DAO); 62 $12^{\prime} 00^{\prime \prime N} 97^{\circ} 53^{\prime} 00^{\prime \prime} \mathrm{W}$, K. Reading 475, 4 Aug. 1984 (DAO) (determined by G. A. Mulligan).

The Mackenzie specimen cited above is an extension of the known range in the Territory of about 250 kilometers northwest of the south end of Bathurst Inlet. To the west it is unknown between there and the Richardson and Mackenzie mountains (Porsild and Cody 1980). The Keewatin specimens cited above are extensions of the known range in the Territory of about 70 kilometers east of the southwesternmost site mapped by Porsild and Cody (1980).

Cardamine pratensis L. Lady's-smock - KEEWATIN: 62 $2^{\circ} 0^{\prime} 00^{\prime \prime N} 97^{\circ} 54^{\prime} 00^{\prime \prime W}$, K. Reading 484, 17 July 1984 (DAO); Pebble Beach Lake, 62 $21^{\circ} 58^{\prime \prime N} 97^{\circ} 30^{\prime} 02^{\prime \prime} \mathrm{W}$, $K$. Reading 483, 10 July 1985 (DAO); south of Bissett Lake, $63^{\circ} 43^{\prime} \mathrm{N} 95^{\circ} 18^{\prime} \mathrm{W}, K$. Reading 482, 22 July 1982 (DAO) (determined by G. A. Mulligan).

The first two specimens cited above are from sites midway between sites near the Hudson Bay Coast and longitude $100^{\circ} \mathrm{W}$. The third specimen cited above is the northernmost yet found in the Territory from south of the Arctic Circle (Porsild and Cody 1980).

Descurainia sophioides (Fisch. ex Hook.) O.E. Schulz - MACKENZIE: Hope Bay Area, northeast of Bathurst Inlet, Roberts Lake, 68 10'30"N 106³3'00"W, K. Reading 254, 3 Aug. 1987 (DAO) (determined by G. A. Mulligan).

The specimen cited above is an extension of the known range in the Territory of about 100 kilometers northeast of a site on the west side of Bathurst Inlet (Porsild and Cody 1980).

Draba fladnizensis Wulf - KEEWATIN: 62 $12^{\prime} 30^{\prime \prime} \mathrm{N}$ 97'52'00"W, K. Reading 507, 3 July 1984 (DAO) (determined by G.A. Mulligan).

The specimen cited above is an extension of the known range in the Territory of about 200 kilometers southeast of a site adjacent to Chesterfield Inlet (Porsild and Cody 1980) (determined by G. A. Mulligan).

Draba juvenalis Kom. (D. longipes Raup) - MACKENZIE: Hope Bay Area, northeast of Bathurst Inlet, Roberts Lake, 68 $10^{\prime} 30^{\prime \prime} \mathrm{N} 106^{\circ} 33^{\prime} 00^{\prime \prime} \mathrm{W}$, K. Reading 500, 12 Aug. 1987 (DAO) (determined by G. A. Mulligan).

The specimen cited above is an extension of the known range in the Territory of about 500 kilometers northeast of the east end of Great Bear Lake. To the northeast it is known from two localities on southeastern Victoria Island (Porsild and Cody 1980). 
Draba nivalis Liljebl. - KeEWATIN: Pebble Beach Lake, 62 $21^{\prime} 40^{\prime \prime N} 97^{\circ} 29^{\prime} 54^{\prime \prime W}, K$. Reading 511, 28 June 1985 (DAO); 62 $11^{\prime} 00^{\prime \prime N} 97^{\circ} 55^{\prime} 00^{\prime \prime W}$, K. Reading 510, 13 July 1984 (DAO) (determined by G. A. Mulligan).

The specimens cited above are from sites midway between sites in the central area of the Territory south of the Arctic Circle and a site in the southeast adjacent to latitude $100^{\circ} \mathrm{W}$ (Porsild and Cody 1980).

Draba wahlenbergii Hartm. (D. lactea Adams) - MACKENZIE: Hope Bay Area, northeast of Bathurst Inlet, Roberts Lake, 68 $10^{\prime} 30^{\prime \prime N} 106^{\circ} 33^{\prime} 00^{\prime \prime W}$, K. Reading 497, 13 July 1990 (DAO); K. Reading 501, 13 Aug. 1987 (DAO); K. Reading 508, 12 Aug. 1987 (DAO); KeEWATIN: Camp 3, 61 $12^{\prime} \mathrm{N} 97^{\circ} 57^{\prime} \mathrm{W}, K$. Reading 499, 13 July 1990 (DAO); 62¹0'30"N 9759'00"W, K. Reading 502, 17 Aug. 1984 (DAO); Imikula Lake, $62^{\circ} 14^{\prime} 00^{\prime N}$ 97 $37^{\prime} 00^{\prime W}, K$. Reading 504, 18 June 1985 (DAO); Big Bird Lake, 62¹7'30"N 97³9'00"W, K. Reading 503, 27 June 1985 (DAO); Pebble Beach Lake, 62 $22^{\prime} 00^{\prime \prime} \mathrm{N} 97^{\circ} 30^{\prime} 00^{\prime \prime} \mathrm{W}, K$. Reading 506, 7 July 1985 (DAO) (determined by G. A. Mulligan).

The District of Mackenzie specimens cited above are from sites about 170 kilometers northeast of the south end of Bathurst Inlet. To the north it is known from southern Victoria Island and is widespread throughout the Arctic Islands. The District of Keewatin specimens are sites midway between sites adjacent to the Hudson Bay Coast and the MackenzieKeewatin border and south of sites north of latitude $63^{\circ} \mathrm{N}$ (Porsild and Cody 1980).

Erysimum pallasii (Pursh) Fern. - MACKENZIE: Hope Bay Area, northeast of Bathurst Inlet, Windy Lake, 6803'11"N 106³7'00"W, K. Reading 298, 14 July 1987 (DAO); KEEWATIN: north side of Mire Creek, 61 $21^{\circ} 00^{\prime \prime N} 97^{\circ} 53^{\prime} 30^{\prime} \mathrm{W}, \mathrm{K}$. Reading 514, 2 July 1990 (DAO) (determined by G. A. Mulligan).

The first specimen cited above is an extension of the known range in the Territory of about 170 kilometers northeast of the south end of Bathurst Inlet (Porsild and Cody 1980). The second specimen is a new record for the District of Keewatin and is an extension of about 765 kilometers southeast of the south end of Bathurst Inlet.

Eutrema edwardsii R.Br. - MACKENZIE: Hope Bay Area, northeast of Bathurst Inlet, Windy Lake, 6803'15"N 106³7'00"W, K. Reading 295, 14 Aug. 1987 (DAO) (determined by G. A. Mulligan).

The specimen cited above is an extension of the known range in the Territory of about 170 kilometers to the northeast from the south end of Bathurst Inlet. To the north it is known on Victoria Island and it is widespread on the Arctic Islands (Porsild and Cody 1980).

Parrya arctica R.Br. - MACKENZIE: Hope Bay Area, northeast of Bathurst Inlet, Roberts Lake, 68 $10^{\prime} 30^{\prime \prime} \mathrm{N}$ 106³3'00"W, K. Reading 476, 10 Aug. 1987 (DAO) (determined by G. A. Mulligan).

The specimen cited above is an extension of the known range in the Territory of about 375 kilometers east of a site west of Coronation Gulf. To the north it is known from Victoria Island and is widespread on the Arctic Islands west of longitude $90^{\circ} \mathrm{W}$ (Porsild and Cody 1980).

\section{SAXIFRAGACEAE}

Chrysosplenium tetrandrum (Lund) Fries - MACKENZIE: rocky lakeshore, Coppermine River Area, 67³3'30"N 116 45'00"W, K. Reading 44, 21 Aug. 2002 (DAO).

The specimen cited above is from a site midway between the south end of Bathurst Inlet and Coppermine (Porsild and Cody 1980).

Saxifraga nelsoniana D. Don ssp. porsildiana (Calder and Savile) Hultén (S. punctata L. ssp. porsildiana Calder \& Savile) - KEEWATIN: Pebble Beach Lake, south of Yathkyed Lake, 62 22'00"N 97³0'00"W, K. Reading 175, 22 July 1985 (DAO).

The specimen cited above is an extension of about 250 kilometers south of the site reported by Cody et al. (2003).

Saxifraga nivalis L., Alpine Saxifrage - MACKEnZIE: wet tundra below scarp, Coppermine River Area, 67³1'12"N 11609'58"W, K. Reading 64, 22 Aug. 2002 (DAO); scarp foot wet, Coppermine River Area, 67²'28"N 116 01'00"W, K. Reading 82, 30 Aug. 2002 (DAO).

The specimens cited above are from sites midway between Bathurst Inlet and Coppermine (Porsild and Cody 1980).

Saxifraga rivularis L. - KEEWATIN: wet shaded rocky ravine south of Wolf Lake, 6339'00"N 95'11'00"W, K. Reading 360, 16 Aug. 1982 (DAO); big esker south of Bissett Lake, 6340'40"N 95³2'00"W, K. Reading 374, 16 Aug. 1981 (DAO); east of Bissett Lake, 6346'00"N 9546'00"W, K. Reading 342, 27 July 1982 (DAO).

The specimens cited above are from sites midway between the Hudson Bay Coast and sites adjacent to longitude $100^{\circ} \mathrm{W}$ (Porsild and Cody 1980).

\section{ROSACEAE}

Potentilla biflora Willd. - MACKENZIE: wet tundra, Coppermine River Area, 66 43'10"N 114 ${ }^{\circ} 58^{\prime} 00^{\prime \prime} \mathrm{W}$, $K$. Reading 523, 7 Sept. 2002 (DAO); rocky tundra and basalt outcrops, Coppermine River Area, 67² $21^{\prime} 00^{\prime \prime} \mathrm{N}$ 115 51'00"W, K. Reading 2, 17 Aug. 2002 (DAO); scarp foot scree, $67^{\circ} 30^{\prime} 10^{\prime \prime} \mathrm{N} 116^{\circ} 10^{\prime} 00^{\prime \prime} \mathrm{W}$, K. Reading 524, 22 Aug. 2002 (DAO); clay tundra boils, Coppermine River Area, 67³1'30"N 116 $14^{\prime} 10^{\prime \prime} \mathrm{W}$, K. Reading 525, 19 Aug. 2002 (DAO); Dismal Lakes, 67²9'N 117³6'W, L.W. Stock s.n., 8 Aug. 1947 (DAO).

The nearest sites of this species to those listed above in this Territory are in the vicinity of the Bluenose Lake Area about 500 kilometers to the northwest (Cody et al. 2003). There is also a site to the northeast on Victoria Island (Porsild and Cody 1980).

Potentilla nivea L. ssp. nivea - KeEwATIN: high dry esker-top, east of Kazan Falls, $63^{\circ} 41^{\prime} \mathrm{N} 95^{\circ} 38^{\prime} \mathrm{W}, K$. Reading 354, 30 Aug. 1982 (DAO); west southwest of Bissett Lake, 634' $30^{\prime \prime} \mathrm{N} 95^{\circ} 28^{\prime} 00^{\prime} \mathrm{W}$, K. Reading 334, 4 Aug. 1982 (DAO); TK camp peninsula, Bissett Lake, 6347'00"N 95²6'30"W, K. Reading 379, 9 Aug. 1982 (DAO).

The specimens cited above are an extension of the known range in the Territory of about 170 kilometers northeast of a site mapped by Porsild and Cody (1980). 
Potentilla palustris (L.) Scop., Marsh Fivefinger KeEwatin: south of Deep Bay of Kazan River, $63^{\circ} 41^{\prime} 30^{\prime \prime N} 95^{\circ} 37^{\prime} 00^{\prime \prime W}, K$. Reading 333, 3 Aug. 1982 (DAO).

The specimen cited above is an extension of the known range of about 170 kilometers northeast of a site in central Keewatin mapped by Porsild and Cody (1980).

Rosa blanda Ait. - MACKENZIE: Mackenzie River Valley

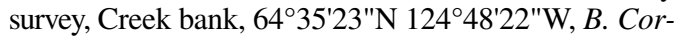
nish s.n., 17 July 2002 (DAO).

Porsild and Cody (1980) knew this species in the Territory only from the vicinity of Wrigley. The specimen cited above is an extension of the known range of about 160 kilometers to the northwest.

Rubus arcticus L. ssp. acaulis (Michx.) Focke - KeEWATIN: Griffin Lake, $61^{\circ} 14^{\prime} 55^{\prime \prime N} 98^{\circ} 46^{\prime} 00^{\prime \prime} \mathrm{W}$, K. Reading 89, 10 Aug. 1990 (DAO).

The specimen cited above is from a site midway between two sites mapped by Porsild and Cody (1980) in southwestern District of Keewatin.

Rubus idaeus L. s.l. (R. strigosus Michx.), Wild Red Raspberry - KeEWATIN: Griffin Lake, 61 18'40"N 98 52'00"W, K. Reading 532, 14 Aug. 1990 (DAO).

Porsild and Cody (1980) knew this species from a single location in the southwest of the Territory. The specimen cited above is an extension of about 100 kilometers to the north.

\section{FABACEAE (LEGUMINOSAE)}

Astragalus australis (L.) Lam. (A. richardsonii Sheldon) - MACKENZIE: Hope Bay Area, northeast of Bathurst Inlet, Roberts Lake, 68 $10^{\prime} 30^{\prime \prime} \mathrm{N} 106^{\circ} 33^{\prime} 00^{\prime \prime} \mathrm{W}$, K. Reading 264, 30 July 1987 (DAO).

The specimen cited above is an extension of the known range in the Territory (Porsild and Cody 1980) of about 170 kilometers northwest of the south end of Bathurst Inlet. To the north it is also known from Victoria Island.

Astragalus eucosmus Robins. - KeEwATIN: west side of Kneeling Man Lake, south of Yathkyed Lake, $62^{\circ} 19^{\prime} 30^{\prime \prime N} 97^{\circ} 33^{\prime} 20^{\prime \prime W}$, K. Reading 187A, 17 July 1985 (DAO); "No-camp" Lake south of Yathkyed Lake, K. Reading 85-17, 15 July 1985 (DAO); "Pebble Beach" Lake, south of Yathkyed Lake, $62^{\circ} 22^{\prime} \mathrm{M}$ $97^{\circ} 30^{\prime} \mathrm{W}, \mathrm{K}$. Reading 85-26, 17 July 1985 (DAO); vicinity of Meliadine Lake, $63^{\circ} 01^{\prime} 44^{\prime \prime} \mathrm{N} 92^{\circ} 10^{\prime} 51^{\prime \prime}$, K. Reading 94-26, 1984 (DAO); on rock outcrop, Rankin Inlet $5 \mathrm{~km}$ northwest of town, $62^{\circ} 49^{\prime} \mathrm{N} 92^{\circ} 05^{\prime} \mathrm{W}$, J. B. Korol s.n., 19 July 1988 (DAO).

The specimens cited above are the first known from the Continental District of Keewatin (Porsild and Cody 1980).

Astragalus eucosmus Robins. f. albinus Fern. - KEEWATIN: north end of No-camp Lake, south of Yathkyed Lake, $62^{\circ} 22^{\prime} 15^{\prime \prime} \mathrm{N} 97^{\circ} 27^{\prime} 10^{\prime \prime} \mathrm{W}$, K. Reading 382, 15 July 1985 (DAO).

This white-flowered form was described by Fernald (1926) on the basis of a specimen from Ha-Ha Mountain in Newfoundland. The specimen cited above is the first known from the Continental Northwest Territories.

Hedysarum alpinum L., Liquorice-root - MACKENZIE: Hope Bay Area, northeast of Bathurst Inlet, Roberts
Lake, $68^{\circ} 10^{\prime} 30^{\prime \prime} \mathrm{N} 106^{\circ} 33^{\prime} 00^{\prime \prime} \mathrm{W}, K$. Reading 236,8 Aug. 1987 (DAO).

The specimen cited above is an extension of the known range in the Territory of about 80 kilometers from a site in the middle of Bathurst Inlet. It is the most northeastern site yet known in the Territory.

Hedysarum boreale Nutt. ssp. mackenzii (Richards.) Welsh (H. mackenzii Richards.) - MACKENZIE: Hope Bay Area, northeast of Bathurst Inlet, Roberts Lake, $68^{\circ} 10^{\prime} 30^{\prime \prime N} 106^{\circ} 33^{\prime} 00^{\prime \prime W}, K$. Reading 237, 8 Aug. 1987 (DAO).

The specimen cited above is an extension of the known range in the Territory of about 170 kilometers northeast of the south end of Bathurst Inlet (Porsild \& Cody 1980). To the north it is known on Victoria Island.

Lupinus arcticus Wats. - MACKENZIE: Hope Bay Area, northeast of Bathurst Inlet, Roberts Lake, $68^{\circ} 10^{\prime} 30^{\prime \prime N} 106^{\circ} 33^{\prime} 00^{\prime W}$, K. Reading 237, 2 Aug. 1987 (DAO).

The specimen cited above is an extension of the known range in the Territory of about 170 kilometers to the northeast of the south end of Bathurst Inlet. To the northeast it is known on Victoria Island (Porsild and Cody 1980).

Oxytropis arctobia Bunge - MACKENZIE: George Lake, south of Bathurst Inlet at the head of Western River, approx. $65^{\circ} 57^{\prime} 20^{\prime \prime} \mathrm{N} 107^{\circ} 30^{\prime} \mathrm{W}, K$. Reading 451, 18 Aug. 1988 (DAO).

The specimen cited above is an extension of the known range in the Territory of about 75 kilometers south of the south end of Bathurst Inlet (Porsild and Cody 1980).

Oxytropis deflexa (Pall.) DC. ssp. foliosa (Hook.) Cody - MACKENZIE: Amphibolite ridge crown, north of the east arm of Great Slave Lake, $62^{\circ} 42^{\prime} \mathrm{N} 113^{\circ} 05^{\prime} \mathrm{W}, K$. Reading 12, 13 Sept. 2002 (DAO).

The specimen cited above is an extension of the known range in the Territory of about 27 kilometers east of a site in the vicinity of Yellowknife (Cody et al. 2003).

Oxytropis maydelliana Trautv. - MACKENZIE: Hope Bay Area, northeast of Bathurst Inlet, Roberts Lake, $68^{\circ} 10^{\prime} 30^{\prime \prime} \mathrm{N} 106^{\circ} 33^{\prime} 00^{\prime \prime W}$, K. Reading 224, 8 Aug. 1987, 244, 6 Aug. 1987 (DAO).

The specimens cited above are an extension of the known range in the Territory of about 170 kilometers northeast of the south end of Bathurst Inlet. To the northeast it is known on Victoria Island (Porsild and Cody 1980).

\section{Callitrichaceae}

Callitriche hermaphroditica L. - MACKENZIE: silty lake bottom, Coppermine River Area, 67³2'55"N $116^{\circ} 13^{\prime} 00^{\prime \prime} \mathrm{W}$, K. Reading 540, 23 Aug. 2002 (DAO).

The specimen cited above which is the northwesternmost yet found in the Territory, is an extension of the known range of about 170 kilometers to the northwest from a site near the east end of Great Bear Lake (Porsild and Cody 1980).

\section{ElEAGNACEAE}

Shepherdia canadensis (L.) Nutt., Soapberry - KeEWATIN: Camp 2, 61201'00"N 9753'30"W, K. Reading 542, 4 July 1990 (DAO). 
The species is new to the flora of mainland Keewatin. It is a southeastward extension of the known range of about 425 kilometers from a site near the eastern limit of the District of Mackenzie (Porsild and Cody 1980).

\section{ONAGRACEAE}

Epilobium davuricum Fisch. - KEEWATIN: dark frostboils, T-Bone Lake, SY, 62 ${ }^{\circ} 13^{\prime} \mathrm{N} 97^{\circ} 53^{\prime} \mathrm{W}$, K. Reading 390, 15 Aug. 1984 (DAO).

The specimen cited above is from a site midway between two sites in the Territory reported by Cody et al. (2003).

Epilobium latifolium L. f. albiflorum Nath. - KEE-

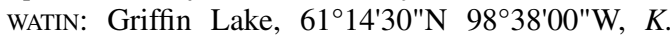
Reading 544, 17 Aug. 1990 (DAO).

Porsild and Cody (1980) stated that the flowers of this species were purple or rarely white, but no localities of the white flower form have previously been reported for this region.

Epilobium palustre L., Swamp Willowherb - MACKENZIE: Hope Bay Area, northeast of Bathurst Inlet, Roberts Lake, 68 $10^{\prime} 30^{\prime \prime N} 106^{\circ} 33^{\prime} 00^{\prime \prime} \mathrm{W}$, K. Reading 247, 6 Aug. 1987 (DAO).

The specimen cited above is an extension of the known range in the Territory of about 170 kilometers to the northeast of a site near the south end of Bathurst Inlet (Porsild and Cody 1980).

\section{HALORAGACEAE}

Myriophyllum alterniflorum DC. - MACKENZIE: Panhandle Lake, SE of Parsons, $68.9104^{\circ} \mathrm{N} 121.555^{\circ} \mathrm{W}$, J. Lancaster 13, 2003 (DAO).

This is a rare species in the Territory (McJannet et al. 1995). The specimen cited above is from a site about 185 kilometers northwest of a site adjacent to the northeast end of Great Bear Lake.

\section{Pyrolaceae}

Moneses uniflora (L.) Gray, One-flowered Pyrola KeEWATIN: Griffin Lake, 61 $16^{\prime} 40^{\prime \prime} \mathrm{N} 98^{\circ} 42^{\prime} 00^{\prime \prime} \mathrm{W}, \mathrm{K}$. Reading 551, 22 July 1990 (DAO); in white spruce copses on tundra, very local, small colonies, north of Griffin Lake, $61^{\circ} 02^{\prime} \mathrm{N} 98^{\circ} 12^{\prime} \mathrm{W}, K$. Reading s.n., 15 Aug. 1990 (DAO).

This species is new to Continental District of Keewatin. The nearest sites known to Porsild and Cody (1980) were near the east end of Great Slave Lake about 700 kilometers to the northwest and adjacent to Hudson Bay in the vicinity of Churchill, Manitoba, about 250 kilometers to the southeast.

Pyrola secunda L. s.1. - KEEWATIN: north of Bissett Lake, 6348'30"N 95²4'00"W, K. Reading 364, 13 Aug. 1982 (DAO).

The specimen cited above is from the central part of the District of Keewatin about 200 kilometers south and 250 kilometers northeast of sites mapped by Porsild and Cody (1980).

\section{ERICACEAE}

Arctostaphylos alpina (L.) Spreng., Alpine Bearberry - MACKENZIE: Hope Bay Area, northeast of Bathurst Inlet, Windy Lake, 6803'15"N 106³7'00"W, K. Reading 291, 7 July 1987 (DAO).
The specimen cited above is an extension of the known range in the Territory of about 80 kilometers to the northeast of a site adjacent to Bathurst Inlet (Porsild and Cody 1980).

Ledum groenlandicum Oeder, Labrador-tea - KEEWATIN: UG Lake, 6245'00"N 98 40'00"W, K. Reading 454, date unknown (DAO); lakeshore, northwest of Imikula Lake, $62^{\circ} 02^{\prime} \mathrm{N} 97^{\circ} 40^{\prime} \mathrm{W}, K$. Reading 459 , July-August 1984 (DAO).

The specimens cited above are the northernmost yet found in the Territory (Porsild and Cody 1980).

Vaccinium vitis-idaea L. var. minus Lodd., Mountain Cranberry - MACKENZIE: Hope Bay Area, northeast of Bathurst Inlet, Roberts Lake, 68 $10^{\prime} 30^{\prime \prime} \mathrm{N} 106^{\circ} 33^{\prime} 00^{\prime \prime} \mathrm{W}$, $K$. Reading 282, 22 July 1987 (DAO).

The specimen cited above is an extension of the known range in the Territory of about 80 kilometers to the east of a site on the west side of Bathurst Inlet (Porsild and Cody 1980).

\section{GENTIANACEAE}

Gentiana affinis Griseb. - MACKENZIE: Mackenzie River Valley pipeline survey, stream bed and low terraces along small creek/with gravel bars upstream, 6322'38"N 12329'35"W, L. Kershaw s.n., 6 Aug. 2002 (DAO); riparian fluvial silt along river, $66.7082^{\circ} \mathrm{N}$ 129.3002 ${ }^{\circ}$ W, L. Kershaw 8, 2003 (DAO).

McJannet et al. (1995) knew this rare species in the Northwest Territories from locations at the west end of Great Slave Lake in the vicinity of Fort Good Hope, Mackenzie Mountains in the vicinity of the Keele River and near Fort Norman. The first specimen cited above is from north of Wrigley. The second specimen is the northernmost yet found in the Territory and is an extension of the known range of about 150 kilometers northwest of Fort Good Hope.

\section{LAMIACEAE}

Lycopus uniflorus Michx., Tuberous Water-horehound - MACKENZIE: muddy run south side of beaver lodge near NW corner lake, $62.9858^{\circ} \mathrm{N} 123.1755^{\circ} \mathrm{W}, L$. Kershaw 11, 2003 (DAO).

This is a rare species in the Territory (McJannet et al. 1995), previously known from only east of the Slave River (Porsild and Cody 1980). The specimen cited above is an extension of the known range in the Territory of about 635 kilometers to the northwest.

\section{SCROPHULARIACEAE}

Lagotis glauca Gaertn. ssp. minor (Willd.) Hultén MACKENZIE: hill west of Canoe Lake, head of creek, $68^{\circ} 15^{\prime} \mathrm{N} 135^{\circ} 54^{\prime} \mathrm{W}$, V. J. Krajina s.n., 11 Aug. 1965 (DAO).

The specimen cited above is from a site about 100 kilometers north of a site mapped by Porsild \& Cody (1980). This site is the northernmost yet found in the Territory.

Limosella aquatica L., Mudwort - MACKENZIE: black spruce/Labrador Tea/cloudberry area in strip of exposed mud, $63.4867^{\circ} \mathrm{N} 123.6914^{\circ} \mathrm{W}$, L. Kershaw 10, 2003 (DAO).

This is a rare species in the Territory (McJannet et al. 1995). The specimen cited above is from a site midway between the 
east end of Great Bear Lake and a site adjacent to the Canol Road in the Yukon Territory.

Pedicularis capitata Adams - MACKENZIE: Hope Bay Area, northeast of Bathurst Inlet, Roberts Lake, $68^{\circ} 10^{\prime} 30^{\prime \prime N} 106^{\circ} 33^{\prime} 00^{\prime \prime W}, K$. Reading 271, 28 July 1987 (DAO).

The specimen cited above is an extension of the known range in the Territory of about 80 kilometers east of a site on the west side of the north end of Bathurst Inlet (Porsild and Cody 1980).

Pedicularis langsdorfii Fisch. ssp. arctica (R.Br.) Pennell ex Hultén (P. arctica R.Br.) - MACKENZIE: Hope Bay Area, northeast of Bathurst Inlet, Roberts Lake, $68^{\circ} 10^{\prime} 30^{\prime \prime N} 106^{\circ} 33^{\prime} 00^{\prime \prime W}, K$. Reading 272, 26 July 1987 (DAO).

The specimen cited above is an extension of the known range in the Territory of about 170 kilometers northeast of a site at the south end of Bathurst Inlet (Porsild and Cody 1980).

Pedicularis lapponica L., Lapland Lousewort - MACKENZIE: Hope Bay Area, northeast of Bathurst Inlet, Roberts Lake, 68 $10^{\prime} 30^{\prime \prime} \mathrm{N} 106^{\circ} 30^{\prime} 00^{\prime \prime} \mathrm{W}$, K. Reading 234, 8 Aug. 1987 (DAO).

The specimen cited above is an extension of the known range in the Territory of about 170 kilometers northeast of the south end of Bathurst Inlet (Porsild and Cody 1980).

Pedicularis macrodonta Richards. (P. parviflora Smith ex Rees var. macrodonta (Richards.) Welsh - MACKENZIE: in graminoid/shrub fen with Juncus stygius, $60.6382^{\circ} \mathrm{N}$ $120.34633^{\circ} \mathrm{W}$, D. Soppet 16, 17 Aug. 2003 (DAO).

This is a rare species in the District of Mackenzie (McJannet et al. 1995). The specimen cited above is only the second known in the Territory and is about 200 kilometers west of the west end of Great Slave Lake.

\section{RUBIACEAE}

Galium trifidum L. - KEEWATIN: among shoreline rocks just north of TK camp, Bissett Lake, 6347'02"N 95²6'31"W, K. Reading 358, 30 Sept. 1982 (DAO).

The specimen cited above is the northernmost yet found in the Territory (Porsild and Cody 1980). It is about 300 kilometers north of the only site known to Porsild and Cody (1980).

\section{CAPRIFOLIACEAE}

Linnaea borealis L. var. americana (Forbes) Rehd., Twinflower - MACKENZIE: spruce "island" on dolomite ridge, Coppermine River Area, 67 $07^{\prime} 00^{\prime \prime} \mathrm{N} 115^{\circ} 45^{\prime} 00^{\prime \prime} \mathrm{W}$, K. Reading 84, 28 Aug. 2002 (DAO).

The specimen cited above is the most northeasterly yet found in the Territory (Porsild and Cody 1980). It is from a site about 250 kilometers northeast of the east end of Great Bear Lake.

\section{CAmpanulaceae}

Campanula uniflora L. - KEEWATIN: west southwest of Bissett Lake, 6343'20"N 95³0'00"W, K. Reading 337, 4 Aug. 1982 (DAO).

The specimen cited above is from a site midway between a site adjacent to the Hudson Bay Coast and a site adjacent to longitude $100^{\circ} \mathrm{W}$ (Porsild and Cody 1980).

\section{Asteraceae}

Antennaria isolepis Greene - KEEWATIN: south of east end of Bissett Lake, 634'00"N 95 11'00"W, K. Readi$n g$ 403, 15 Aug. 1982 (DAO); south of Bissett Lake, 6341'30"N 95¹8'00"W, K. Reading 418, 22 July 1982 (DAO); 10 miles northeast of Bissett Lake, 6356'99"N 9507'00"W, K. Reading 405, 3 July 1981 (DAO).

The specimens cited above are from sites about 200 kilometers northeast and southeast of sites about longitude $99^{\circ} \mathrm{W}$ in the Territory (Porsild and Cody 1980).

Arnica angustifolia Vahl in Hornem. ssp. attenuata (Greene) Douglas \& Ruyle-Douglas (A. alpina (L.) Olin ssp. attenuata (Greene) Maguire) - MACKENZIE: Coppermine River Area, scarp slope, K. Reading 33, 19 Aug. 2002 (DAO); foot of scarp in sand, 67³1'10"N 11609'54"W, K. Reading 54, 22 Aug. 2002 (DAO); sand/gravel ridge, $67^{\circ} 23^{\prime} 45^{\prime \prime} \mathrm{N} 116^{\circ} 27^{\prime} 00^{\prime \prime} \mathrm{W}$, K. Reading 32, 16 Aug. 2002 (DAO).

The specimens cited above extend the known distribution in the Territory about 170 kilometers to the northeast from a site adjacent to the southeast end of Great Bear Lake (Porsild and Cody 1980).

Arnica chamissonis Less. - MACKENZIE: Yellowknife Area, roadside clearing, Boulder Bay, 62 $32^{\prime} 00^{\prime \prime} \mathrm{N}$ $113^{\circ} 20^{\prime} 00^{\prime \prime W}, K$. Reading 11, 11 Sept. 2002 (DAO).

The specimen cited above is from a site about 170 kilometers northwest of a site on the south side of eastern Great Slave Lake.

Artemisia furcata Bieb. (A. hyperborea Rydb.) MACKENZIE: Coppermine River Area, 67³2'30"N $116^{\circ} 00^{\prime} 00^{\prime \prime W}, K$. Reading 582, 29 Aug. 2002 (DAO).

The specimen cited above is an extension of the known range in the Territory of about 160 kilometers to the southeast of a site west of Coppermine and northeast of a site at the west end of Great Bear Lake (Porsild and Cody 1980).

Artemisia tilesii Ledeb. s.1. - MACKENZIE: Hope Bay Area, northeast of Bathurst Inlet, $68^{\circ} 10^{\prime} 30^{\prime \prime} \mathrm{N}$ 106³3'00"W, K. Reading 248, 3 Aug. 1987 (DAO).

The specimen cited above is an extension of the known range in the Territory of about 170 kilometers northeast of a site near the south end of Bathurst Inlet (Porsild and Cody 1980). It is the northeasternmost site yet known in the Territory.

Aster puniceus L., Purple-stemmed Aster - MACKENZIE: in calcareous area where stream widens and pools on flat area before flowing into mineral lake, Wrigley area, $62.7307^{\circ} \mathrm{N} 123.1098^{\circ} \mathrm{W}$, D. Soppet 26B, 2003 (DAO).

Porsild and Cody (1980) suggested that this species should be looked for on the Salt Plain west of Fort Smith. The specimen cited above is from a site about 730 kilometers northwest of a site mapped near the west end of Lake Athabasca by Porsild and Cody.

Aster pygmaeus Lindl. - MACKENZIE: Hope Bay Area, northeast of Bathurst Inlet, Roberts Lake, 68 $10^{\prime} 30^{\prime \prime} \mathrm{N}$ 106³3'00"W, K. Reading 225, 9 Aug. 1987 (DAO).

The specimen cited above is an extension of the known range in the Territory of about 125 kilometers northeast of a site about the middle of Bathurst Inlet and it is the northeasternmost yet known in the Territory (Porsild and Cody 1980). 
Aster sibiricus L. - MACKENZIE: Coppermine River Area, foot of scarp, sandy, 67³1'10"N 116 $09^{\circ} 54^{\prime \prime} \mathrm{W}$, K. Reading 55, 22 Aug. 2002 (DAO); sandy slope near scarp, 67 $32 ' 50^{\prime \prime} \mathrm{N} 116^{\circ} 13^{\prime} 00^{\prime \prime} \mathrm{W}, K$. Reading 584, 23 Aug. 2002 (DAO).

The specimens cited above are from sites midway between the south end of Bathurst Inlet and the vicinity of Coppermine (Porsild and Cody 1980).

Crepis nana Richards. - MACKENZIE: Hope Bay Area, northeast of Bathurst Inlet, Windy Lake, 68 $03^{\prime} 15^{\prime \prime} \mathrm{N}$ 106³7'00"W, K. Reading 300, 14 July 1987 (DAO); George Lake, south of Bathurst Inlet at the head of Western River, 65 $57^{\prime} 20^{\prime \prime} \mathrm{N}, 107^{\circ} 30^{\prime} \mathrm{W}, K$. Reading 453, 18 Aug. 1988 (DAO); sandy ridge, Coppermine River Area, 67 $24^{\prime} 00^{\prime \prime} \mathrm{N} 116^{\circ} 24^{\prime} 00^{\prime \prime} \mathrm{W}, K$. Reading 586, 18 Aug. 2002 (DAO).

The first specimen cited above is an extension of the known range in the Territory of about 170 kilometers northeast of the south end of Bathurst Inlet. The second specimen is from a site about 170 kilometers northwest of the south end of Bathurst Inlet (Porsild and Cody 1980).

Erigeron uniflorus L. ssp. eriocephalus (Vahl. ex Hornem.) Cronq. (E. eriocephalus Vahl. ex Hornem.) MACKENZIE: Coppermine River Area, sand ridge near creek, 67²3'00"N 116 27'00"W, K. Reading 595, 16 Aug. 2002 (DAO).

The specimen cited above is from a site midway between the vicinity of Coppermine and the south end of Bathurst Inlet (Porsild and Cody 1980).

Matricaria ambigua (Ledeb.) Kryl., Sea-shore Camomile - MACKENZIE: Hope Bay Area, northeast of Bathurst Inlet, Roberts Lake, 68 $10^{\prime} 30^{\prime \prime} \mathrm{N} 106^{\circ} 33^{\prime} 00^{\prime \prime} \mathrm{W}$, K. Reading 268, 30 July 1987 (DAO); Windy Lake, 6803'15"N 106³7'00"W, K. Reading 290, 7 July 1987 (DAO).

The specimens cited above are an extension of the known range in the Territory of about 170 kilometers northeast of the south end of Bathurst Inlet (Porsild and Cody 1980).

Senecio congestus (R.Br.) DC. - MACKENZIE: Hope Bay Area, northeast of Bathurst Inlet, Roberts Lake, $68^{\circ} 10^{\prime} 30^{\prime \prime N} 106^{\circ} 33^{\prime} 00^{\prime \prime W}, K$. Reading 232, 10 Aug. 1987 (DAO).

The specimen cited above is an extension of the known range in the Territory of about 170 kilometers to the northeast from the south end of Bathurst Inlet (Porsild and Cody 1980).

Solidago graminifolia (L.) Salisb. var. major (Michx.) Fern. (Euthamis graminifolia (L.) Nutt. var. graminifolia) - MACKENZIE: clearing with coarse rocks as soil base, \#3 bay south of R.R.T.P. Camp, Tsu Lake, $60^{\circ} 35^{\prime} \mathrm{N} 111^{\circ} 52^{\prime} \mathrm{W}$, J. Thompson s.n., 19 Aug. 1980 (DAO); rocky shoreline, 250 metres west of Tsu Lake camp, $60^{\circ} 35^{\prime} \mathrm{N} 111^{\circ} 52^{\prime} \mathrm{W}$, D. Campbell s.n., 19 Aug. 1980 (DAO); river banks, $63.4719^{\circ} \mathrm{N} 123.7029^{\circ} \mathrm{W}, L$. Kershaw 27, 2003.

Porsild and Cody (1980) and McJannet et al. (1995) knew this rare plant in the Territory only from the vicinity of Fort
Simpson. The first two specimens cited above are from sites northeast of Lake Athabasca. The third specimen is a northward extension adjacent to the Mackenzie River of about 100 kilometers from the northernmost mapped by Porsild and Cody (1980).

\section{Acknowledgments}

We thank the many individuals who have contributed specimens to the DAO Herbarium; George Argus for the identification of Salix; Gerry Mulligan for the identification of Cruciferae; Leslie Cody for the many hours inputting this information on her computer; and Paul Catling for reviewing an earlier version of this manuscript.

\section{Literature Cited}

Argus, G. W. 2001. A Guide to the identification of willows in Alaska, the Yukon Territory and adjacent regions (published privately).

Cody, W. J., M. Blondeau, and J. Cayouette. 1988. Ranunculus $\times$ spitzbergensis (Nath.) Hadac, An addition to the flora of North America. Rhodora 90: 27-36.

Cody, W. J., K. L. MacInnes, J. Cayouette, and S. Darbyshire. 2000. Alien and Invasive Native Plants along the Norman Wells Pipeline, District of Mackenzie, Northwest Territories, Canadian Field-Naturalist 114: 126-137.

Cody, W. J., K. L. Reading, and J. M. Line. 2003. Additions and Range Extensions to the Vascular Plant Flora of the Continental Northwest Territories and Nunavut, Canada II. Canadian Field-Naturalist 117: 448-465.

Cody, W. J., G. W. Scotter, and S. C. Zoltai. 1984. Additions to the Vascular Plant Flora of Bathurst Inlet, Northwest Territories, Canada. Canadian Field-Naturalist 98: 171-177.

Cody, W. J., G. W. Scotter, and S. C. Zoltai. 1992. Vascular Plant Flora of the Melville Hills Region, Northwest Territories. Canadian Field-Naturalist 106: 87-99.

Cody, W. J. and S. S. Talbot. 1978. Vascular Plant Range Extensions to the Heart Lake Area, District of Mackenzie, Northwest Territories. Canadian Field-Naturalist 92: 137143.

Haynes, R. R. 1974. A Revision of North American Potamogeton subsection Pusilli (Potamogetonaceae). Rhodora 76: 564-649.

Fernald, M. L. 1926. Two summers of botanizing in Newfoundland. Rhodora 28: 215.

McJannet, C. L., G. W. Argus, and W. J. Cody. 1995. Rare Vascular Plants in the Northwest Territories. Syllogeus 73, Canadian Museum of Nature, Ottawa. 104 pages.

Porsild, A. E. 1939. Notes on the occurrence of Zostera and Zanichellia in arctic North America. Rhodora 73: 90-94.

Porsild, A. E., and W. J. Cody. 1980. Vascular Plants of Continental Northwest Territories, Canada. National Museum of Natural Sciences, Ottawa. 667 pages.

Scotter, G. W., and W. J. Cody. 1974. Vascular Plants of Nahanni National Park and Vicinity, Northwest Territories, Naturaliste Canadien 101: 861-891.

Thieret, J. W. 1961. New Plant Records for Southwestern District of Mackenzie, Canadian Field-Naturalist 75: 111121.

Received 20 October 2004

Accepted 11 March 2005 